Prepared in Cooperation with the Letterkenny Army Depot

\title{
Baseline Environmental Monitoring of Groundwater, Surface Water, and Soil at the Ammonium Perchlorate Rocket Motor Destruction Facility at the Letterkenny Army Depot, Chambersburg, Pennsylvania, 2016
}

Open-File Report 2019-1094 



\section{Baseline Environmental Monitoring of Groundwater, Surface Water, and Soil at the Ammonium Perchlorate Rocket Motor Destruction Facility at the Letterkenny Army Depot, Chambersburg, Pennsylvania, 2016}

By Daniel G. Galeone

Prepared in Cooperation with the Letterkenny Army Depot

Open-File Report 2019-1094 


\title{
U.S. Department of the Interior DAVID BERNHARDT, Secretary
}

\author{
U.S. Geological Survey \\ James F. Reilly II, Director
}

\section{U.S. Geological Survey, Reston, Virginia: 2019}

For more information on the USGS - the Federal source for science about the Earth, its natural and living resources, natural hazards, and the environment-visit https://www.usgs.gov or call 1-888-ASK-USGS.

For an overview of USGS information products, including maps, imagery, and publications, visit https://store.usgs.gov.

Any use of trade, firm, or product names is for descriptive purposes only and does not imply endorsement by the U.S. Government.

Although this information product, for the most part, is in the public domain, it also may contain copyrighted materials as noted in the text. Permission to reproduce copyrighted items must be secured from the copyright owner.

Suggested citation:

Galeone, D.G., 2019, Baseline environmental monitoring of groundwater, surface water, and soil at the Ammonium Perchlorate Rocket Motor Destruction Facility at the Letterkenny Army Depot, Chambersburg, Pennsylvania, 2016: U.S Geological Survey Open-File Report 2019-1094, 32 p., https://doi.org/10.3133/ofr20191094.

Associated data for this publication:

Galeone, D.G., 2019, Quality control and soil quality data in support of baseline environmental monitoring at the Ammonium Perchlorate Rocket Motor Destruction (ARMD) Facility at the Letterkenny Army Depot, Chambersburg, Pennsylvania, 2016: U.S. Geological Survey data release, https://doi.org/10.5066/P973YRPL.

ISSN 2331-1258 (online) 


\section{Contents}

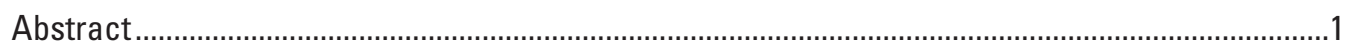

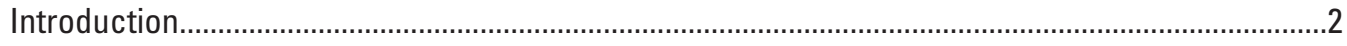

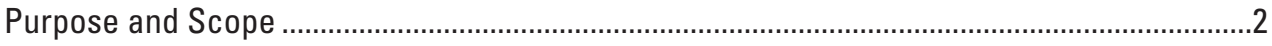

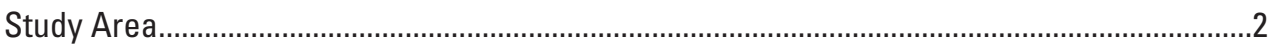

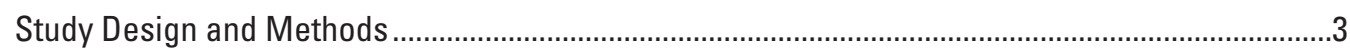

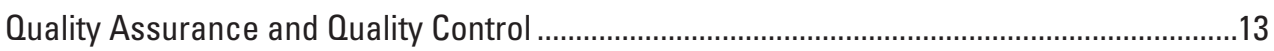

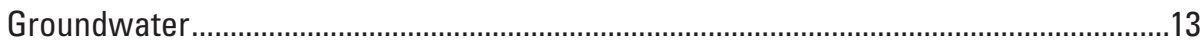

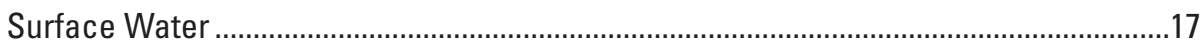

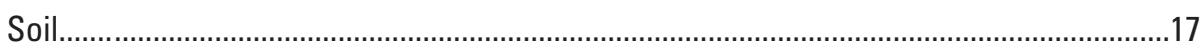

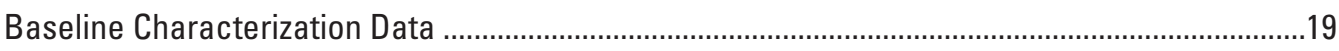

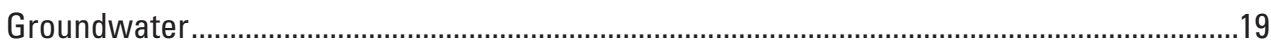

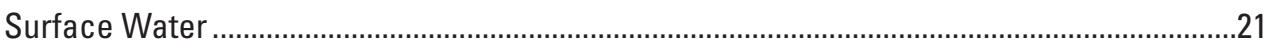

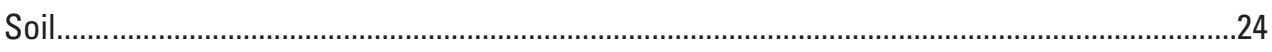

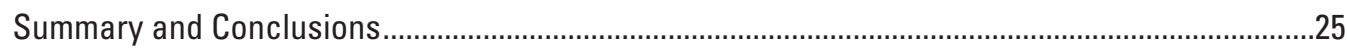

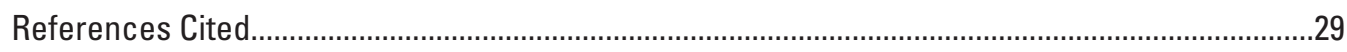

Appendix 1. Description of wells and constituent concentrations in groundwater samples from four wells at the Ammonium Perchlorate Rocket Motor Destruction Facility at the Letterkenny Army Depot, Pennsylvania, September-December 2016 ..........................32

Appendix 2. Monthly ranges of volatile organic compounds in matrix-spike samples analyzed internally at ALS laboratory for soil samples submitted from the Ammonium Perchlorate Rocket Motor Destruction Facility at the Letterkenny Army Depot, Pennsylvania, September-December 2016.

Appendix 3. Description of surface-water sites and constituents in surface-water samples collected near the Ammonium Perchlorate Rocket Motor Destruction Facility at the Letterkenny Army Depot, Pennsylvania, September-December 2016.

Appendix 4. Description of soil sites and constituent concentrations in soil samples collected at the Ammonium Perchlorate Rocket Motor Destruction Facility at the Letterkenny Army Depot, Pennsylvania, September-December 2016.

\section{Figures}

1. Photo of the Ammonium Perchlorate Rocket Motor Destruction Facility at the Letterkenny Army Depot in Chambersburg, Pennsylvania, during construction, summer 2016

2. Map showing underlying geology and locations of well and surface-water sampling sites at the Ammonium Perchlorate Rocket Motor Destruction Facility at the Letterkenny Army Depot, Pennsylvania, 2016.

3. Map showing location of surface-water, storm-runoff, and soil sampling sites and groundwater monitoring wells at the Ammonium Perchlorate Rocket Motor Destruction Facility, Letterkenny Army Depot, Pennsylvania, 2016

4. Photo of well MW-3 at the Ammonium Perchlorate Rocket Motor Destruction Facility at the Letterkenny Army Depot, Pennsylvania, June 9, 2016.

5. Photo of surface-water site SW-U at the Ammonium Perchlorate Rocket Motor Destruction Facility at the Letterkenny Army Depot, Pennsylvania, September 13, 2016 


\section{Figures-Continued}

6. Photo of dry conditions at surface-water site SW-1D taken at the Ammonium Perchlorate Rocket Motor Destruction Facility at the Letterkenny Army Depot, Pennsylvania, December 7, 2016.

7. Photo of a retention basin that captures runoff water from areas adjacent to the Ammonium Perchlorate Rocket Motor Destruction Facility at the Letterkenny Army Depot, Pennsylvania, June 9, 2016.

8. Photo of a culvert at storm-runoff site ST-B at the Ammonium Perchlorate Rocket Motor Destruction Facility at the Letterkenny Army Depot, Pennsylvania, September 27, 2016.

9. Photo of soil sampling site SO-4 at the Ammonium Perchlorate Rocket Motor Destruction Facility at the Letterkenny Army Depot, Pennsylvania, June 9, 2016.

10. Photo of soil sampling site SO-5 at the Ammonium Perchlorate Rocket Motor Destruction Facility at the Letterkenny Army Depot, Pennsylvania, June 9, 2016

11. Graphs showing measured and mean values of water temperature, dissolved oxygen, $\mathrm{pH}$, specific conductance, water level, and turbidity for water samples collected at the four monitoring wells at the Ammonium Perchlorate Rocket Motor Destruction Facility at the Letterkenny Army Depot, Pennsylvania, September-December 2016

12. Graphs showing measured and mean concentrations of dissolved iron, molybdenum, barium, arsenic, chromium, and bismuth in water samples collected from four monitoring wells at the Ammonium Perchlorate Rocket Motor Destruction Facility at the Letterkenny Army Depot, Pennsylvania, September-December 2016

13. Graphs showing measured and mean concentrations of chloride, sulfate, fluoride, phosphorus, dissolved silica, and dissolved potassium concentrations in water samples collected from four monitoring wells at the Ammonium Perchlorate Rocket Motor Destruction Facility at the Letterkenny Army Depot, Pennsylvania, September-December 2016

14. Map showing drainage area for surface-water site SW-U at the Ammonium Perchlorate Rocket Motor Destruction Facility at the Letterkenny Army Depot, Pennsylvania, 2016

15. Graphs showing measured and mean concentrations of arsenic, lead, chromium, copper, mercury, and selenium in soil samples collected from the nine soil sites at the Ammonium Perchlorate Rocket Motor Destruction Facility at the Letterkenny Army Depot, Pennsylvania, September-December 2016

16. Graphs showing measured and mean concentrations of iron, molybdenum, barium, bismuth, aluminum, and zirconium concentrations in soil samples collected from the nine soil sites at the Ammonium Perchlorate Rocket Motor Destruction Facility at the Letterkenny Army Depot, Pennsylvania, September-December 2016

17. Graphs showing measured and mean concentrations of chloride, sulfate, potassium, silica, fluoride, and phosphorus in soil samples collected from the nine soil sites at the Ammonium Perchlorate Rocket Motor Destruction Facility at the Letterkenny Army Depot, Pennsylvania, September-December 2016 


\section{Tables}

1. Constituents, Reporting Detection Levels, and methods of analysis for water and soil samples collected at the Ammonium Perchlorate Rocket Motor

Destruction Facility at the Letterkenny Army Depot, Pennsylvania,

September-December 2016.

2. Description of wells drilled at the Ammonium Perchlorate Rocket Motor Destruction Facility at the Letterkenny Army Depot, Pennsylvania, May 16-17, 2016

3. Lithology at four wells at the Ammonium Perchlorate Rocket Motor Destruction Facility at the Letterkenny Army Depot, Pennsylvania.

4. Descriptions of nine soil sampling sites at the Ammonium Perchlorate Rocket Motor Destruction Facility at the Letterkenny Army Depot, Pennsylvania, 2016

5. Relative percent differences for selected constituents between routine and replicate groundwater samples from four wells at the Ammonium Perchlorate Rocket Motor Destruction Facility at the Letterkenny Army Depot, Pennsylvania, 2016

6. Relative percent differences for selected constituents between routine and replicate soil samples collected at the Ammonium Perchlorate Rocket Motor Destruction Facility at the Letterkenny Army Depot, Pennsylvania, September-December 2016.

7. Minimum, mean, and maximum values for selected constituents in surface-water samples collected at site SW-U near the Ammonium Perchlorate Rocket Motor Destruction Facility at the Letterkenny Army Depot, Pennsylvania, September-December 2016.

\section{Conversion Factors}

U.S. customary units to International System of Units

\begin{tabular}{lcl}
\hline & Multiply & \multicolumn{1}{c}{ To obtain } \\
\hline inch (in.) & Length & \\
inch (in.) & 2.54 & centimeter $(\mathrm{cm})$ \\
foot (ft) & 25.4 & millimeter $(\mathrm{mm})$ \\
mile (mi) & 0.3048 & meter $(\mathrm{m})$ \\
\hline & 1.609 & kilometer $(\mathrm{km})$ \\
\hline acre & Area & \\
acre & 4,047 & square meter $\left(\mathrm{m}^{2}\right)$ \\
acre & 0.4047 & hectare $($ ha) \\
square foot $\left(\mathrm{ft}^{2}\right)$ & 0.004047 & square kilometer $\left(\mathrm{km}^{2}\right)$ \\
square foot $\left(\mathrm{ft}^{2}\right)$ & 929.0 & square centimeter $\left(\mathrm{cm}^{2}\right)$ \\
square mile $\left(\mathrm{mi}^{2}\right)$ & 0.09290 & square meter $\left(\mathrm{m}^{2}\right)$ \\
square mile $\left(\mathrm{mi}^{2}\right)$ & 259.0 & hectare $($ ha) \\
\hline & 2.590 & square kilometer $\left(\mathrm{km}^{2}\right)$ \\
\hline gallon $($ gal $)$ & Volume & \\
gallon $(\mathrm{gal})$ & 3.785 & liter $(\mathrm{L})$ \\
\hline
\end{tabular}




\section{Conversion Factors-Continued}

U.S. customary units to International System of Units

\begin{tabular}{lcl}
\hline \multicolumn{1}{c}{ Multiply } & By & \multicolumn{1}{c}{ To obtain } \\
\hline gallon per minute $(\mathrm{gal} / \mathrm{min})$ & Flow rate & \\
inch per year $(\mathrm{in} / \mathrm{yr})$ & 0.06309 & liter per second $(\mathrm{L} / \mathrm{s})$ \\
cubic foot per second $\left(\mathrm{ft}^{3} / \mathrm{s}\right)$ & 25.4 & millimeter per year $(\mathrm{mm} / \mathrm{yr})$ \\
& 0.02832 & cubic meter per second $\left(\mathrm{m}^{3} / \mathrm{s}\right)$ \\
\hline ounce, avoirdupois $(\mathrm{oz})$ & Mass & gram $(\mathrm{g})$ \\
\hline
\end{tabular}

Temperature in degrees Celsius $\left({ }^{\circ} \mathrm{C}\right)$ may be converted to degrees Fahrenheit $\left({ }^{\circ} \mathrm{F}\right)$ as follows:

$$
{ }^{\circ} \mathrm{F}=\left(1.8 \times{ }^{\circ} \mathrm{C}\right)+32 .
$$

\section{Datum}

Vertical coordinate information is referenced to the North American Vertical Datum of 1988 (NAVD 88).

Horizontal coordinate information is referenced to North American Datum of 1983 (NAD 83).

Elevation, as used in this report, refers to distance above the vertical datum.

\section{Supplemental Information}

Specific conductance is given in microsiemens per centimeter at 25 degrees Celsius $(\mu \mathrm{S} / \mathrm{cm}$ at $\left.25^{\circ} \mathrm{C}\right)$.

Concentrations of chemical constituents in water are given in either milligrams per liter (mg/L) or micrograms per liter $(\mu \mathrm{g} / \mathrm{L})$.

\section{Abbreviations}

$\begin{array}{ll}\text { ARMD } & \text { Ammonium Perchlorate Rocket Motor Destruction } \\ \text { CFR } & \text { Code of Federal Regulations } \\ \text { DO } & \text { Dissolved oxygen } \\ \text { EPA } & \text { U.S. Environmental Protection Agency } \\ \text { LEAD } & \text { Letterkenny Army Depot } \\ \text { MCL } & \text { Maximum Contaminant Level } \\ \text { MSC } & \text { Medium-specific concentrations } \\ \text { MS/MSD } & \text { Matrix-spike and matrix-spike duplicate } \\ \text { MTBE } & \text { Methyl tert-butyl ether }\end{array}$




\section{Abbreviations-Continued}

$\begin{array}{ll}\text { NTUs } & \text { Nephelometric Turbidity Units } \\ \text { PADEP } & \text { Pennsylvania Department of Environmental Protection } \\ \text { OA/OC } & \text { Quality assurance and quality control } \\ \text { RDLs } & \text { Reporting Detection Levels } \\ \text { RPD } & \text { Relative percent difference } \\ \text { SC } & \text { Specific conductance } \\ \text { SMCL } & \text { Secondary Maximum Contaminant Level } \\ \text { SSL } & \text { Soil screening level } \\ \text { USGS } & \text { U.S. Geological Survey } \\ \text { VOCS } & \text { Volatile organic compounds }\end{array}$





\title{
Baseline Environmental Monitoring of Groundwater, Surface Water, and Soil at the Ammonium Perchlorate Rocket Motor Destruction Facility at the Letterkenny Army Depot, Chambersburg, Pennsylvania, 2016
}

\author{
By Daniel G. Galeone
}

\section{Abstract}

Letterkenny Army Depot in Chambersburg, Pennsylvania, built an Ammonium Perchlorate Rocket Motor Destruction (ARMD) facility in 2016. The ARMD Facility was designed to centralize rocket motor destruction and contain or capture all waste during the destruction process. Ideally, there would be no contaminant transport to air, soil, or water from the facility, but the Code of Federal Regulations requires that any hazardous waste disposal facility have an environmental monitoring program in place. In a study by the U.S. Geological Survey, in cooperation with the Letterkenny Army Depot, baseline characterization of constituents in groundwater, surface water, and soil was conducted from September to December 2016 to document site conditions prior to the beginning of operations at the facility in January 2017. Groundwater wells, surface water, and soils were sampled monthly during the baseline characterization period. No sediment transport from the site occurred on days when samples were collected from surface-water sites, so no sediment was collected from the retention basin at the facility during the baseline period. Data collected during the baseline period can be compared to data collected in future years to determine whether there is any contaminant transport from the ARMD Facility to the surrounding environment.

During the baseline characterization period, monthly samples were collected from 4 groundwater wells and 9 soil sites near the ARMD Facility. The only surface-water site sampled monthly during the baseline period was upgradient from the facility. There was no streamflow at surface-water sites downgradient from the facility on days when surfacewater samples were collected during the baseline characterization period.

Groundwater results for the four wells sampled near the ARMD Facility during the baseline period did not show any major water-quality issues. Mean specific conductance (SC) and $\mathrm{pH}$ in groundwater ranged from 220 to 771 microsiemens per centimeter at 25 degrees Celsius $(\mu \mathrm{S} / \mathrm{cm})$ and 6.45 to 6.98 , respectively. No constituents in groundwater samples exceeded any U.S. Environmental Protection Agency (EPA) Maximum Contaminant Level (MCL). Dissolved iron (Fe) was the only groundwater constituent that exceeded a Secondary Maximum Contaminant Level (SMCL) established by the EPA. The SMCL for Fe is 300 micrograms per liter $(\mu \mathrm{g} / \mathrm{L})$; samples from three wells had mean dissolved Fe concentrations ranging from 1,100 to $2,600 \mu \mathrm{g} / \mathrm{L}$. The only volatile organic compounds (VOCs) detected in groundwater samples were bromomethane, acetone, and chloromethane. All VOC detections in groundwater samples were less than the Reporting Detection Levels (RDLs). These three compounds also were detected in blank samples submitted for groundwater samples. Perchlorate was not detected in any groundwater sample collected during the baseline period.

Surface-water data collected during the baseline period were strictly representative of a stream reach upgradient from the ARMD Facility. Stream discharge ranged from 0.03 to 0.08 cubic feet per second during sample collection. The mean $\mathrm{SC}$ and $\mathrm{pH}$ were $310 \mu \mathrm{S} / \mathrm{cm}$ and 7.6, respectively. No EPA established MCLs or SMCLs were exceeded for any constituents in samples collected from this upgradient stream. Some VOCs were detected in surface water at less than the RDLs. The VOCs detected in surface water were generally the same VOCs as those detected at less than the RDLs for groundwater. Perchlorate was detected in each sample collected from the stream; the mean concentration was $0.07 \mu \mathrm{g} / \mathrm{L}$. All perchlorate results were less than the RDL of $0.2 \mu \mathrm{g} / \mathrm{L}$.

Soil samples collected during the baseline period did not have any constituent concentrations that exceeded any medium-specific concentrations (MSC) or soil screening levels (SSL) established by either the Commonwealth of Pennsylvania or the EPA. The Commonwealth of Pennsylvania calculates MSCs based on either a function of acceptable concentrations in groundwater or based on health concerns if the soil is directly contacted. The EPA derives acceptable concentrations of constituents (SSLs) in soil based on standardized equations combining exposure information assumptions with EPA toxicity data. The EPA calculates SSLs for residential and industrial sites. Soil sites at the ARMD Facility were 
considered "industrial" for comparative purposes. There was at least one order of magnitude difference between any inorganic constituent concentration detected in soil and the MSC and (or) SSL for that constituent. Four VOCs were detected in soil samples collected during the baseline period. None of the VOCs detected in the soils were within three orders of magnitude of any established MSCs or SSLs. The VOCs detected in soil were dichloromethane (also known as methylene chloride), methyl tert-butyl ether (MTBE), tetrachloroethene, and acetone (only detected once). Dichloromethane was the only VOC detected at greater than the RDLs; concentrations in all soil samples were greater than the RDLs. Dichloromethane concentrations ranged from 1.9 to 50.1 micrograms per kilogram $(\mu \mathrm{g} / \mathrm{kg})$. MTBE was detected in 50 percent of samples collected but all results were less than the RDLs of 1.7 to $2.6 \mu \mathrm{g} / \mathrm{kg}$. Tetrachloroethene was detected in 20 percent of soil samples collected, with a maximum estimated value of $1.5 \mu \mathrm{g} / \mathrm{kg}$. Inorganic constituents with the highest concentrations in soil were $\mathrm{Fe}$ and aluminum $(\mathrm{Al})$; mean $\mathrm{Fe}$ and $\mathrm{Al}$ concentrations ranged from 28,700 to 52,400 and 10,300 to 19,800 milligrams per kilogram $(\mathrm{mg} / \mathrm{kg})$, respectively. Data collected during the baseline period in 2016 can be compared to future data to determine whether concentrations in water and soils surrounding the facility have shown any changes that could be caused by the facility operation.

\section{Introduction}

Letterkenny Army Depot (LEAD), located near Chambersburg, Pennsylvania, is a Federal government facility that provides supply and maintenance support to the U.S. Armed Forces. LEAD overhauls, rebuilds, modifies, tests, and repairs a wide variety of missile systems ranging from air-launched missiles to large ground-based air defense missile systems. LEAD also receives, stores, issues, renovates, and demilitarizes conventional ammunition (Redhorse Corporation, 2016). In 2016, LEAD completed a new destruction facility, the Ammonium Perchlorate Rocket Motor Destruction (ARMD) Facility, which uses confined burning with emissions control to treat solid propellant rocket motors that were previously treated at uncontained outdoor grounds at LEAD. The ARMD Facility conducts static firing of full motors and containment and capture of the exhaust for treatment in a pollution abatement system. The structures at the facility include the confined burn unit and two buildings that will be used for processing and de-segmenting the rocket motors. The ARMD Facility is a contained burn treatment facility for demilitarization of rocket motors, the byproduct of which is a non-hazardous solid waste, with no planned releases to surface water, groundwater, soils, stormwater runoff, or runoff sediment. However, 40 Code of Federal Regulations (CFR) Part 264 (Standards for Owners and Operators of Hazardous Waste Treatment, Storage, And Disposal Facilities), Subpart F (Releases from Solid Waste Management Units) requires monitoring and response programs (Code of Federal Regulations, 2018; Redhorse Corporation, 2016).

To meet the CFR requirements for monitoring, an environmental sampling plan was developed by Redhorse Corporation (2016) in coordination with LEAD and the Pennsylvania Department of Environmental Protection (PADEP). The U.S. Geological Survey (USGS), in cooperation with Letterkenny Army Depot, conducted a study to measure the characteristics and constituents in groundwater, surface water, and soil during a baseline period from September to December 2016. The environmental monitoring conducted prior to the operation of the ARMD Facility was needed to establish baseline concentrations of indicator compounds that could result from unplanned releases to soil, surface water, groundwater, stormwater runoff, or runoff sediment, from the ARMD Facility. The beginning of facility operation in January 2017 terminated the baseline characterization period; therefore, no baseline samples were collected in spring and summer. Data collected during the baseline period in 2016 can be compared to subsequent sampling data to determine whether operations at the ARMD Facility are adversely affecting the surrounding environment.

\section{Purpose and Scope}

This report presents the results for baseline sampling and analysis to characterize groundwater, surface water, and soils at the ARMD Facility at the Letterkenny Army Depot from September 2016 through December 2016, prior to the beginning of facility operation in January 2017 . The findings for constituent concentrations in groundwater, surface water, and soil during the baseline period are summarized in this report. Quality-assurance and quality-control (QA/QC) sample analysis results and soil sample analysis results presented in this report are available online at https://doi.org/10.5066/ P973YRPL.

\section{Study Area}

The ARMD Facility (fig. 1) is in a remote area of LEAD that is used for a variety of purposes including missile maintenance, ammunition storage, and the Open Burning and Open Detonation grounds. Some fallow/forage land surrounds the immediate vicinity of the facility. Land to the west (approximately 4,000 feet from ARMD) is primarily forested and slopes upward to Broad Mountain. Elevations at LEAD range from approximately 600 to 800 feet above the North American Vertical Datum of 1988 (NAVD 88) in the valley below Broad Mountain.

The LEAD facility is in the Cumberland Valley part of the Great Valley in the easternmost section of the Ridge and Valley Province of the Appalachian Mountains, approximately 3.5 miles southwest of Upper Strasburg, Pennsylvania. The Ordovician-aged bedrock underlying the ARMD Facility and surrounding landscape varies moving from west to east. The 


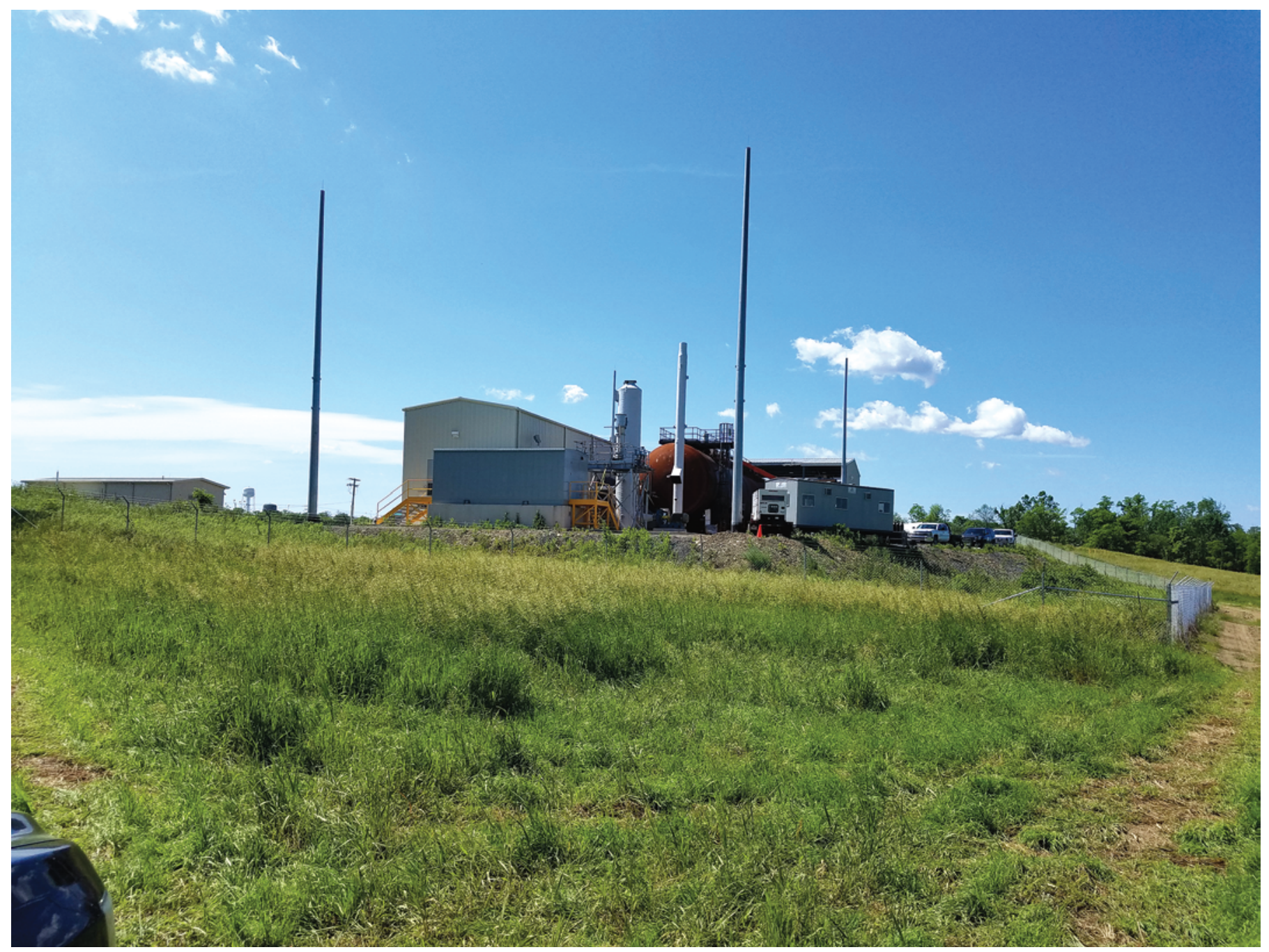

Figure 1. Photo of the Ammonium Perchlorate Rocket Motor Destruction Facility at the Letterkenny Army Depot in Chambersburg, Pennsylvania, during construction, summer 2016.

facility itself is underlain by shales of the Martinsburg Formation. Adjacent land to the west is underlain by argillaceous limestone of the Chambersburg Formation, and a bit further to the west land is underlain by limestone of the St. Paul Group (fig. 2). Precipitation in the area averages about 42 inches per year, and the mean annual temperature is about 11 degrees Celsius $\left({ }^{\circ} \mathrm{C}\right.$; Pennsylvania State Climatologist, 2018).

Native soils in the vicinity of the ARMD Facility are channery silt loams or silt loams, typically well drained. The building and immediate vicinity consist of soils identified as Weikert channery silt loam. This silt loam typically forms on the side slopes of ridges and is well drained. Depth to bedrock is about 20 inches. The soil is derived from weathered shale and siltstone (U.S. Department of Agriculture, 2018a). Other soils surrounding the facility are found in settings from mountain slopes to depressions and flood plains. The soils in flood plain/depression land forms (Melvin silt loam and
Brinkerton silt loam) are poorly drained and are either alluvium or colluvium derived from sedimentary rocks. The soils typically formed on hillslopes (Berks channery silt loam and Swanpond-Edom complex) are well drained and derived from residuum weathered from limestone, shale, or siltstone (U.S. Department of Agriculture, 2018a).

\section{Study Design and Methods}

The ARMD is a fully contained unit for demilitarization of rocket motors, the byproduct of which is a non-hazardous solid waste, with no planned releases to surface water, groundwater, soils, or stormwater runoff catchments. The monitoring program approach was designed to establish baseline concentrations of indicator compounds that could result from unplanned releases to soil, surface water, groundwater, or 


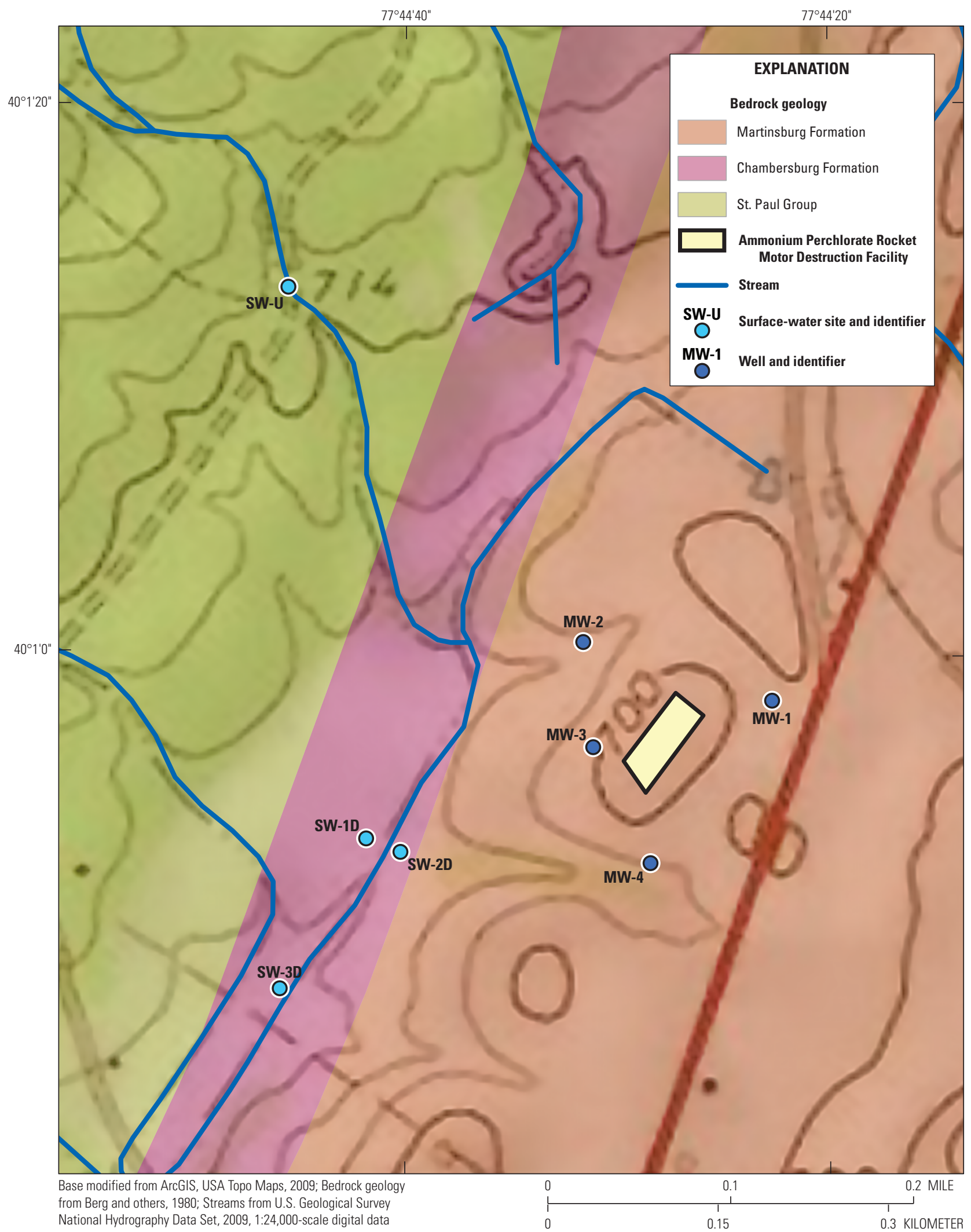

Figure 2. Underlying geology and locations of well and surface-water sampling sites at the Ammonium Perchlorate Rocket Motor Destruction Facility at the Letterkenny Army Depot, Pennsylvania, 2016. 
stormwater runoff from the ARMD Facility (Redhorse Corporation, 2016). Once baseline conditions are established during 2016 prior to the beginning of the facility operation, the monitoring program would transition to annual sampling in 2017 when the facility became operational. An increase in indicator compound concentration or other change from baseline concentrations or a change from downgradient versus upgradient concentrations in soil, surface water, groundwater, or stormwater runoff could indicate a release has occurred at the ARMD Facility. The baseline characterization period was from September to December 2016. Monthly samples were collected from wells, streams, and soils during this period.

Field characteristics for water samples were measured using a multiparameter sonde. The sonde was used to measure water temperature, $\mathrm{pH}$, specific conductance (SC), dissolved oxygen (DO), and Eh. Eh is a measure of the oxidation reduction potential in millivolts. A portable turbidimeter was used to measure turbidity. The sonde was calibrated each morning prior to sample collection. Calibration of the turbidimeter is checked semiannually.

Constituents for environmental monitoring were selected at the request of PADEP. The initial constituent list was determined on the basis of the system design information, controls, rocket motor combustion byproducts, proximal facility operations, characteristics of liquid and solid waste at the site, materials used, material storage, and material handling methods. Samples were collected from water and soils according to standard USGS field methods (U.S. Geological Survey, variously dated), unless otherwise noted, and were analyzed for total (unfiltered) nutrients, dissolved trace metals, major ions, total volatile organic compounds (VOCs), total perchlorate, and dissolved zirconium ( $\mathrm{Zr}$; see table 1 for a complete listing).

The sample sites (fig. 3) for this project were determined by PADEP in collaboration with Letterkenny staff and private consultants working for LEAD. Surface-water sites and groundwater-monitoring wells were identified upgradient and downgradient from the ARMD Facility. Two storm-runoff sites and nine soil sampling sites in the vicinity of the ARMD Facility and associated parking areas were identified.

Four groundwater monitoring wells are in the study area, one upgradient (MW-1) and three downgradient (MW-2, MW-3, and MW-4) from the facility (figs. 3). The four monitoring wells were completed (air rotary drill technique) in the Ordovician-aged Martinsburg Formation and range in depth from 22 to 81 feet (table 2). A photo of MW-3 is provided in figure 4. The Martinsburg Formation, which is present at the site of well MW-3, is predominantly composed of black carbonaceous shale with a thin basal unit of platy limestone (Becher and Taylor, 1982). The lithology described by Steven Read (Read and Associates, written commun., 2016) is representative of wells completed in the Martinsburg Formation (table 3). These four wells are relatively shallow with 6-inch casings at depths of 3-18 feet below land surface. The 6-inch steel casing protects the inner 2-inch polyvinyl chloride casing that extends to the depth of the slotted screened interval.
Wells were grouted from land surface to above the slotted screened interval. Bentonite plugs of 1-4 feet in length above the screened interval protect the screen from surface water traveling down the annulus; sand packing surrounds the slotted screen below the bentonite plug to the bottom of the well (Steven Read, Read and Associates, written commun., 2016).

Dedicated bladder pumps (and Teflon-lined tubing) were installed in each well in August 2016 to promote low-flow sampling at flow rates less than 1 gallon per minute (gal $/ \mathrm{min})$. Pumps were positioned at varying heights above the bottom of the well hole. Bladder pumps were positioned at approximately the center of the slotted screened interval for each well (table 2). Static water levels were recorded prior to purging. Flow rates during sampling ranged from 0.1 to $0.8 \mathrm{gal} / \mathrm{min}$ (appendix 1). Samples for analysis were collected after field characteristics ( $\mathrm{pH}, \mathrm{DO}, \mathrm{Eh}, \mathrm{SC}$, water temperature, and turbidity) were stable. Field characteristics were recorded every 5 minutes. Typically, wells were purged for 30-40 minutes before samples were collected for analyses. The number of well volumes purged prior to sampling ranged from 0.4 to 10.4 , with an average purge of about 4 well volumes. Only samples collected for metals and $\mathrm{Zr}$ were filtered through a 0.45 -micron capsule filter (table 1). All other analyses were conducted on unfiltered water. All groundwater samples were placed on ice immediately after sample collection and delivered to the ALS laboratory in Middletown, Pa., the day of sample collection.

The four surface-water sampling sites are near the ARMD Facility, one upgradient (SW-U) and three downgradient (SW-1D, SW-2D, and SW-3D) from the facility (fig. 3). Only one of these stream locations (SW-U) is perennial (fig. 5). The stream sampling sites downgradient from the facility were not flowing when the samples were collected from September to December 2016 (fig. 6). In addition to the field characteristics measured in groundwater samples, stream discharge was measured at the time of sample collection. Stream discharge was measured either volumetrically or with an acoustic doppler velocity flow meter. A volumetric measurement was made if the stream depth was less than 0.3 feet at the culvert outflow at SW-U. A volumetric measurement involved placing a container immediately below the culvert pipe at SW-U for a specified time (less than 10 seconds), then measuring the volume.

The width of SW-U at the time of sample collection was approximately 3 feet, so samples bottles were simply dipped into the stream and filled. Only samples collected for metals and $\mathrm{Zr}$ were filtered through a 0.45-micron capsule filter (table 1). All other analyses were conducted on unfiltered water. All surface-water samples were placed on ice immediately after sample collection and delivered to the ALS laboratory the day of sample collection. 
Table 1. Constituents, Reporting Detection Levels, and methods of analysis for water and soil samples collected at the Ammonium Perchlorate Rocket Motor Destruction Facility at the Letterkenny Army Depot, Pennsylvania, September-December 2016.

[RDL, Reporting Detection Level; $\mu \mathrm{g} / \mathrm{L}$, micrograms per liter; $\mu \mathrm{g} / \mathrm{kg}$, micrograms per kilogram; mg/L, milligrams per liter; mg/kg, milligrams per kilogram; diss, dissolved; N, nitrogen; \%, percent]

\begin{tabular}{|c|c|c|c|c|c|c|}
\hline \multirow[t]{2}{*}{ Constituent } & \multicolumn{3}{|c|}{ Water } & \multicolumn{3}{|c|}{ Soil } \\
\hline & Unit & RDL Range & Method & Unit & RDL Range & Method \\
\hline Acetone & $\mu \mathrm{g} / \mathrm{L}$ & 10 & SW846 8260B ${ }^{1}$ & $\mu \mathrm{g} / \mathrm{kg}$ & $8.4-12.8$ & SW846 8260B \\
\hline Benzene & $\mu \mathrm{g} / \mathrm{L}$ & 1 & SW846 8260B & $\mu \mathrm{g} / \mathrm{kg}$ & $1.7-2.6$ & SW846 8260B \\
\hline Bromodichloromethane & $\mu \mathrm{g} / \mathrm{L}$ & 1 & SW846 8260B & $\mu \mathrm{g} / \mathrm{kg}$ & $1.7-2.6$ & SW846 8260B \\
\hline Bromoform & $\mu \mathrm{g} / \mathrm{L}$ & 1 & SW846 8260B & $\mu \mathrm{g} / \mathrm{kg}$ & $1.7-2.6$ & SW846 8260B \\
\hline Bromomethane & $\mu \mathrm{g} / \mathrm{L}$ & 1 & SW846 8260B & $\mu \mathrm{g} / \mathrm{kg}$ & $1.7-2.6$ & SW846 8260B \\
\hline Chlorobenzene & $\mu \mathrm{g} / \mathrm{L}$ & 1 & SW846 8260B & $\mu \mathrm{g} / \mathrm{kg}$ & $1.7-2.6$ & SW846 8260B \\
\hline Chlorodibromomethane & $\mu \mathrm{g} / \mathrm{L}$ & 1 & SW846 8260B & $\mu \mathrm{g} / \mathrm{kg}$ & $1.7-2.6$ & SW846 8260B \\
\hline Chloroethane & $\mu \mathrm{g} / \mathrm{L}$ & 1 & SW846 8260B & $\mu \mathrm{g} / \mathrm{kg}$ & $4.2-6.4$ & SW846 8260B \\
\hline Chloromethane & $\mu \mathrm{g} / \mathrm{L}$ & 1 & SW846 8260B & $\mu \mathrm{g} / \mathrm{kg}$ & $1.7-2.6$ & SW846 8260B \\
\hline Cyclohexane & $\mu \mathrm{g} / \mathrm{L}$ & 1 & SW846 8260B & $\mu \mathrm{g} / \mathrm{kg}$ & $1.7-2.6$ & SW846 8260B \\
\hline 1,2-Dibromo-3-chloropropane & $\mu \mathrm{g} / \mathrm{L}$ & 7 & SW846 8260B & $\mu \mathrm{g} / \mathrm{kg}$ & $4.2-6.4$ & SW846 8260B \\
\hline 1,2-Dibromoethane & $\mu \mathrm{g} / \mathrm{L}$ & 1 & SW846 8260B & $\mu \mathrm{g} / \mathrm{kg}$ & $1.7-2.6$ & SW846 8260B \\
\hline 1,1-Dichloroethane & $\mu \mathrm{g} / \mathrm{L}$ & 1 & SW846 8260B & $\mu \mathrm{g} / \mathrm{kg}$ & $1.7-2.6$ & SW846 8260B \\
\hline 1,2-Dichloroethane & $\mu \mathrm{g} / \mathrm{L}$ & 1 & SW846 8260B & $\mu \mathrm{g} / \mathrm{kg}$ & $1.7-2.6$ & SW846 8260B \\
\hline 1,1-Dichloroethene & $\mu \mathrm{g} / \mathrm{L}$ & 1 & SW846 8260B & $\mu \mathrm{g} / \mathrm{kg}$ & $1.7-2.6$ & SW846 8260B \\
\hline cis-1,2-Dichloroethene & $\mu \mathrm{g} / \mathrm{L}$ & 1 & SW846 8260B & $\mu \mathrm{g} / \mathrm{kg}$ & $1.7-2.6$ & SW846 8260B \\
\hline trans-1,2-Dichloroethene & $\mu \mathrm{g} / \mathrm{L}$ & 1 & SW846 8260B & $\mu \mathrm{g} / \mathrm{kg}$ & $1.7-2.6$ & SW846 8260B \\
\hline 1,2-Dichloropropane & $\mu \mathrm{g} / \mathrm{L}$ & 1 & SW846 8260B & $\mu \mathrm{g} / \mathrm{kg}$ & $1.7-2.6$ & SW846 8260B \\
\hline cis-1,3-Dichloropropene & $\mu \mathrm{g} / \mathrm{L}$ & 1 & SW846 8260B & $\mu \mathrm{g} / \mathrm{kg}$ & $1.7-2.6$ & SW846 8260B \\
\hline trans-1,3-Dichloropropene & $\mu \mathrm{g} / \mathrm{L}$ & 1 & SW846 8260B & $\mu \mathrm{g} / \mathrm{kg}$ & $1.7-2.6$ & SW846 8260B \\
\hline 1,4-Dioxane & $\mu \mathrm{g} / \mathrm{L}$ & 320 & SW846 8260B & $\mu \mathrm{g} / \mathrm{kg}$ & $63.2-96.3$ & SW846 8260B \\
\hline Ethylbenzene & $\mu \mathrm{g} / \mathrm{L}$ & 1 & SW846 8260B & $\mu \mathrm{g} / \mathrm{kg}$ & $1.7-2.6$ & SW846 8260B \\
\hline Freon 113 & $\mu \mathrm{g} / \mathrm{L}$ & 1 & SW846 8260B & $\mu \mathrm{g} / \mathrm{kg}$ & $1.7-2.6$ & SW846 8260B \\
\hline
\end{tabular}


Table 1. Constituents, Reporting Detection Levels, and methods of analysis for water and soil samples collected at the Ammonium Perchlorate Rocket Motor Destruction Facility at the Letterkenny Army Depot, Pennsylvania, September-December 2016. - Continued

[RDL, Reporting Detection Level; $\mu \mathrm{g} / \mathrm{L}$, micrograms per liter; $\mu \mathrm{g} / \mathrm{kg}$, micrograms per kilogram; mg/L, milligrams per liter; mg/kg, milligrams per kilogram; diss, dissolved; N, nitrogen; \%, percent]

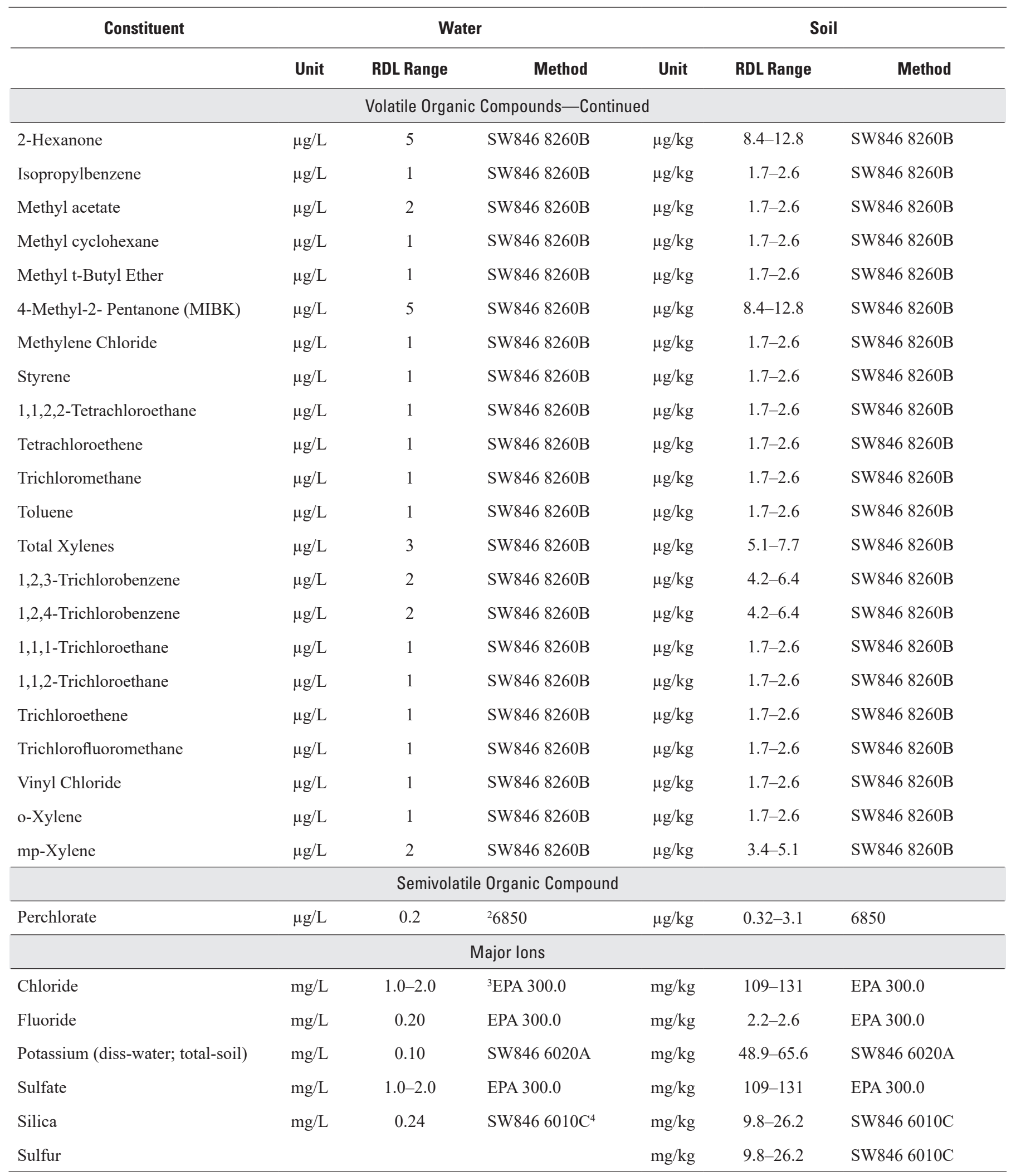


Table 1. Constituents, Reporting Detection Levels, and methods of analysis for water and soil samples collected at the Ammonium Perchlorate Rocket Motor Destruction Facility at the Letterkenny Army Depot, Pennsylvania, September-December 2016.—Continued

[RDL, Reporting Detection Level; $\mu \mathrm{g} / \mathrm{L}$, micrograms per liter; $\mu \mathrm{g} / \mathrm{kg}$, micrograms per kilogram; mg/L, milligrams per liter; mg/kg, milligrams per kilogram; diss, dissolved; N, nitrogen; \%, percent]

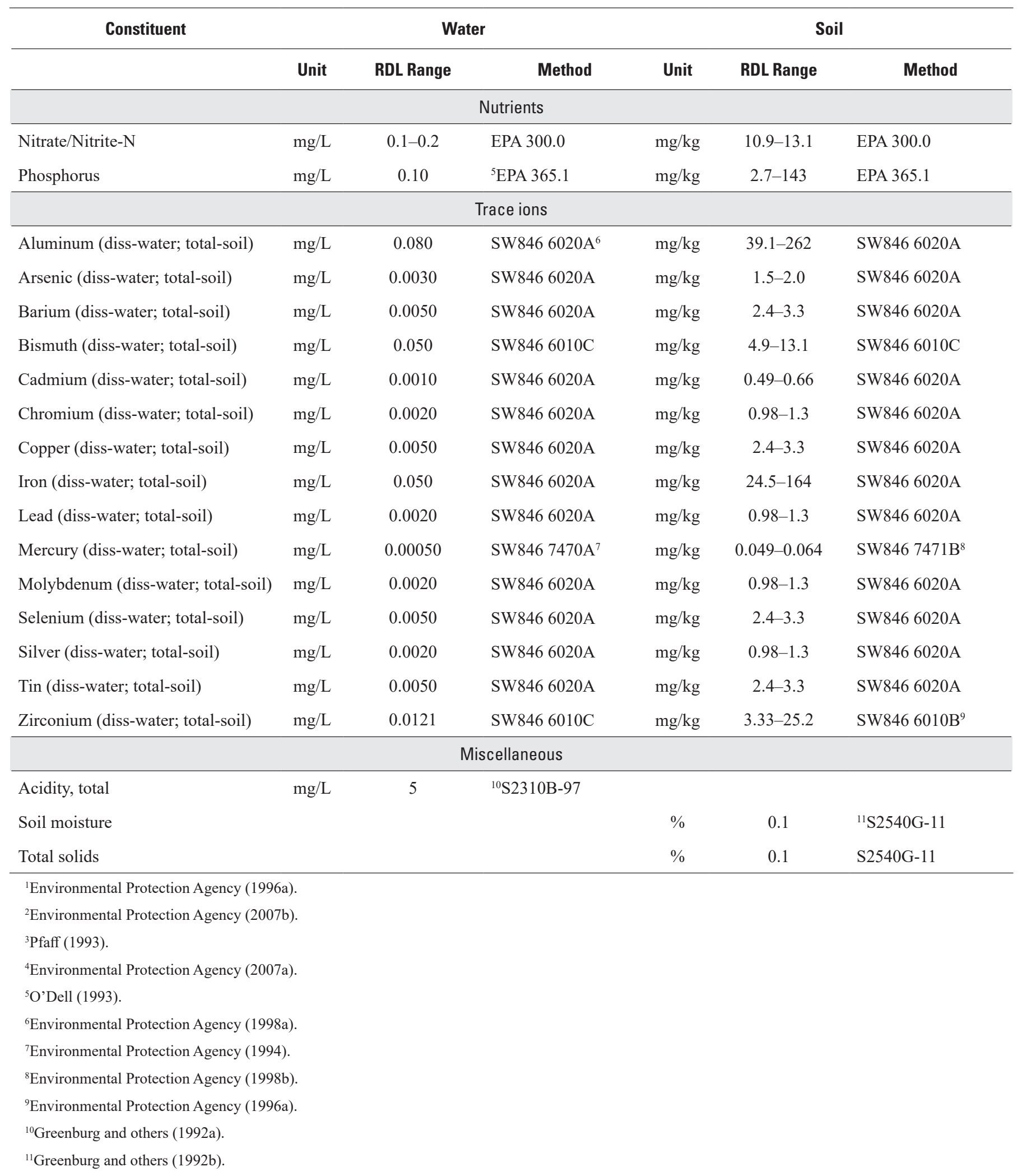




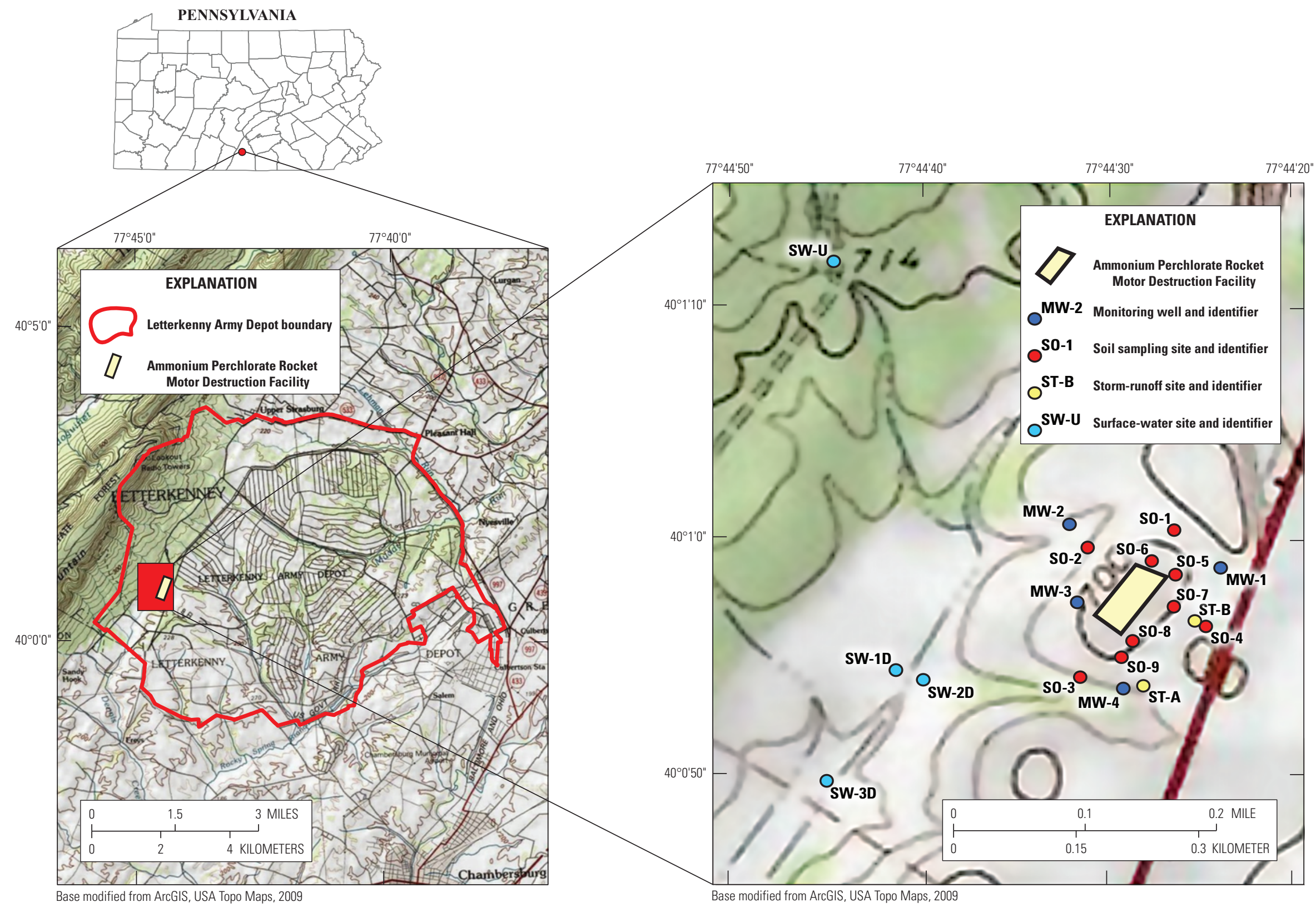

Figure 3. Location of surface-water, storm-runoff, and soil sampling sites and groundwater monitoring wells at the Ammonium Perchlorate Rocket Motor Destruction Facility, Letterkenny Army Depot, Pennsylvania, 2016. 
Table 2. Description of wells drilled at the Ammonium Perchlorate Rocket Motor Destruction Facility at the Letterkenny Army Depot, Pennsylvania, May 16-17, 2016.

[ft, foot; NAVD 88, North American Vertical Datum of 1988; gal/min, gallons per minute]

\begin{tabular}{|c|c|c|c|c|c|c|c|c|c|c|c|}
\hline $\begin{array}{l}\text { Station } \\
\text { identifier }\end{array}$ & $\begin{array}{c}\text { Local } \\
\text { well } \\
\text { number }\end{array}$ & $\begin{array}{l}\text { Local } \\
\text { name }\end{array}$ & $\begin{array}{l}\text { Latitude, } \\
\text { in } \\
\text { decimal } \\
\text { degrees }\end{array}$ & $\begin{array}{l}\text { Longitude, } \\
\text { in } \\
\text { decimal } \\
\text { degrees }\end{array}$ & $\begin{array}{c}\text { Ground } \\
\text { elevation, } \\
\text { in ft above } \\
\text { NAVD } 88\end{array}$ & $\begin{array}{l}\text { Well } \\
\text { depth, } \\
\text { in ft }\end{array}$ & $\begin{array}{l}\text { Measuring } \\
\text { point, height } \\
\text { above land } \\
\text { surface, in } \mathrm{ft}\end{array}$ & $\begin{array}{l}\text { Six-inch } \\
\text { casing } \\
\text { depth } \\
\text { below } \\
\text { land } \\
\text { surface, } \\
\text { in } \mathrm{ft}\end{array}$ & $\begin{array}{c}\text { Slotted } \\
\text { screen } \\
\text { depth } \\
\text { below } \\
\text { land } \\
\text { surface, } \\
\text { in ft }\end{array}$ & $\begin{array}{c}\text { Pump } \\
\text { depth } \\
\text { below } \\
\text { land } \\
\text { surface, } \\
\text { in ft }\end{array}$ & $\begin{array}{c}\text { Well } \\
\text { yield, in } \\
\text { gal/min' }\end{array}$ \\
\hline 400101077443201 & FR 839 & MW-2 & 40.01682 & 77.74236 & 678.88 & 22 & 1.57 & 3 & $5-22$ & 13 & 2.9 \\
\hline 400057077443201 & FR 840 & MW-3 & 40.01589 & 77.74229 & 702.60 & 81 & 1.24 & 14.5 & $36-81$ & 58 & 1.6 \\
\hline 400053077443001 & FR 841 & MW-4 & 40.01485 & 77.74168 & 682.85 & 41 & 1.25 & 12.3 & $31-41$ & 36 & 5.2 \\
\hline
\end{tabular}

${ }^{1}$ Well yields measured by Steven Read (Read and Associates, written commun., 2016).

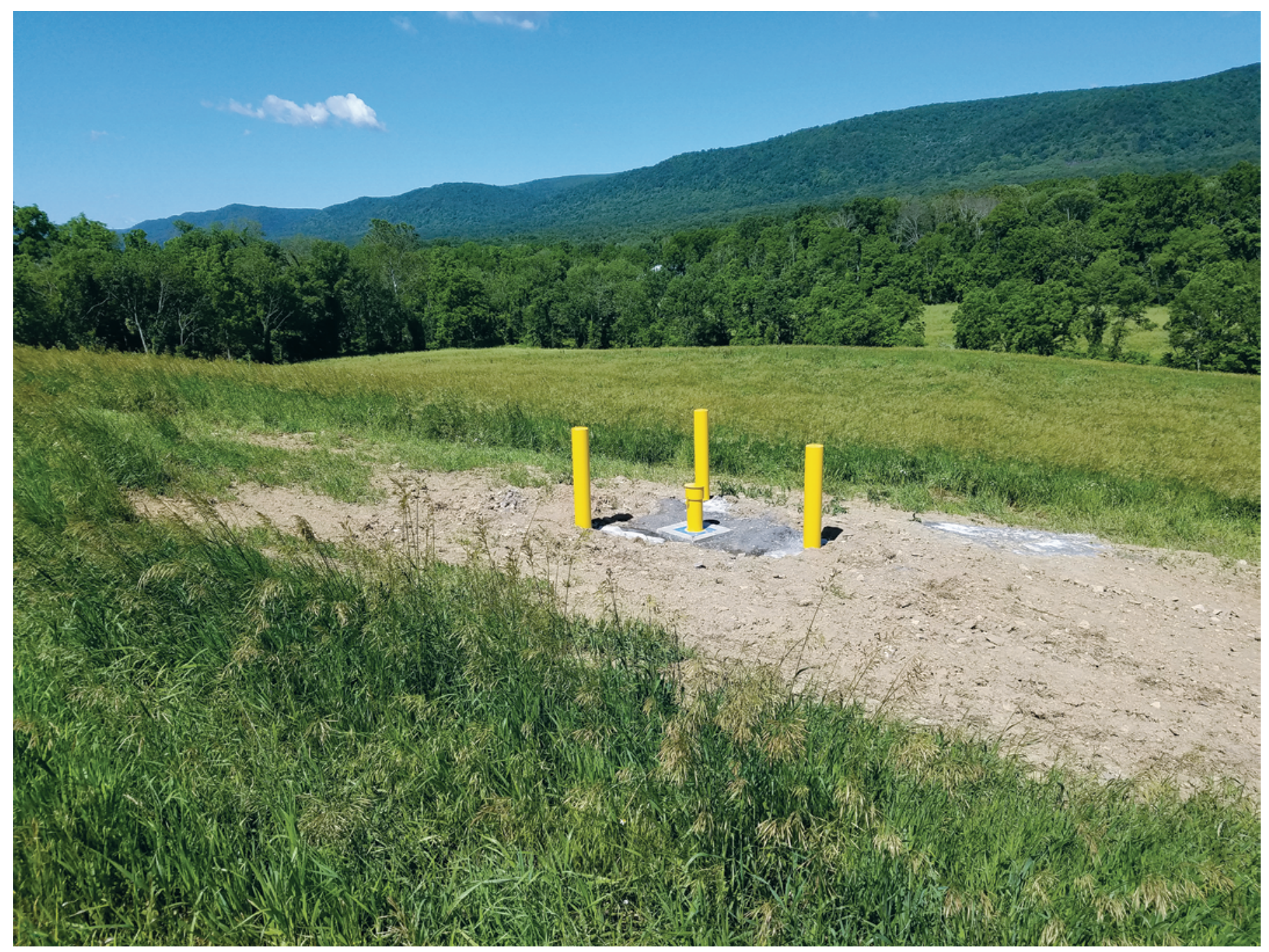

Figure 4. Photo of well MW-3 at the Ammonium Perchlorate Rocket Motor Destruction Facility at the Letterkenny Army Depot, Pennsylvania, June 9, 2016. 
Table 3. Lithology at four wells at the Ammonium Perchlorate Rocket Motor Destruction Facility at the Letterkenny Army Depot, Pennsylvania. Modified from Steven Read, Read and Associates, written commun. (2016).

[Depth is feet below land surface]

\begin{tabular}{|c|c|c|c|c|c|c|c|}
\hline \multicolumn{8}{|c|}{ Well } \\
\hline \multicolumn{2}{|r|}{ MW-1 } & \multicolumn{2}{|r|}{ MW-2 } & \multicolumn{2}{|r|}{ MW-3 } & \multicolumn{2}{|r|}{ MW-4 } \\
\hline $\begin{array}{l}\text { Depth, } \\
\text { in feet }\end{array}$ & Lithology & $\begin{array}{l}\text { Depth, } \\
\text { in feet }\end{array}$ & Lithology & $\begin{array}{l}\text { Depth, } \\
\text { in feet }\end{array}$ & Lithology & $\begin{array}{l}\text { Depth, } \\
\text { in feet }\end{array}$ & Lithology \\
\hline $0-3$ & Topsoil $\rightarrow$ subsoil & $0-6$ & Topsoil $\rightarrow$ subsoil & $0-0.5$ & Topsoil $\rightarrow$ subsoil & $0-3$ & Topsoil $\rightarrow$ subsoil \\
\hline $3-15$ & $\begin{array}{l}\text { Grayish black silty } \\
\text { shale }\end{array}$ & $6-10$ & Mudstone & $0.5-27$ & $\begin{array}{l}\text { Dark-gray silty } \\
\text { limestone }\end{array}$ & $3-21$ & Dark-gray silty shale \\
\hline $22-35$ & $\begin{array}{l}\text { Dark-gray siltstone } \\
\text { grades to shale }\end{array}$ & $20-22$ & Dary-gray limestone & $32-81$ & $\begin{array}{l}\text { Dark-gray silty } \\
\text { limestone }\end{array}$ & 41 & Bottom of well \\
\hline $35-41.3$ & Grayish-black shale & 22 & Bottom of well & 81 & Bottom of well & & \\
\hline
\end{tabular}

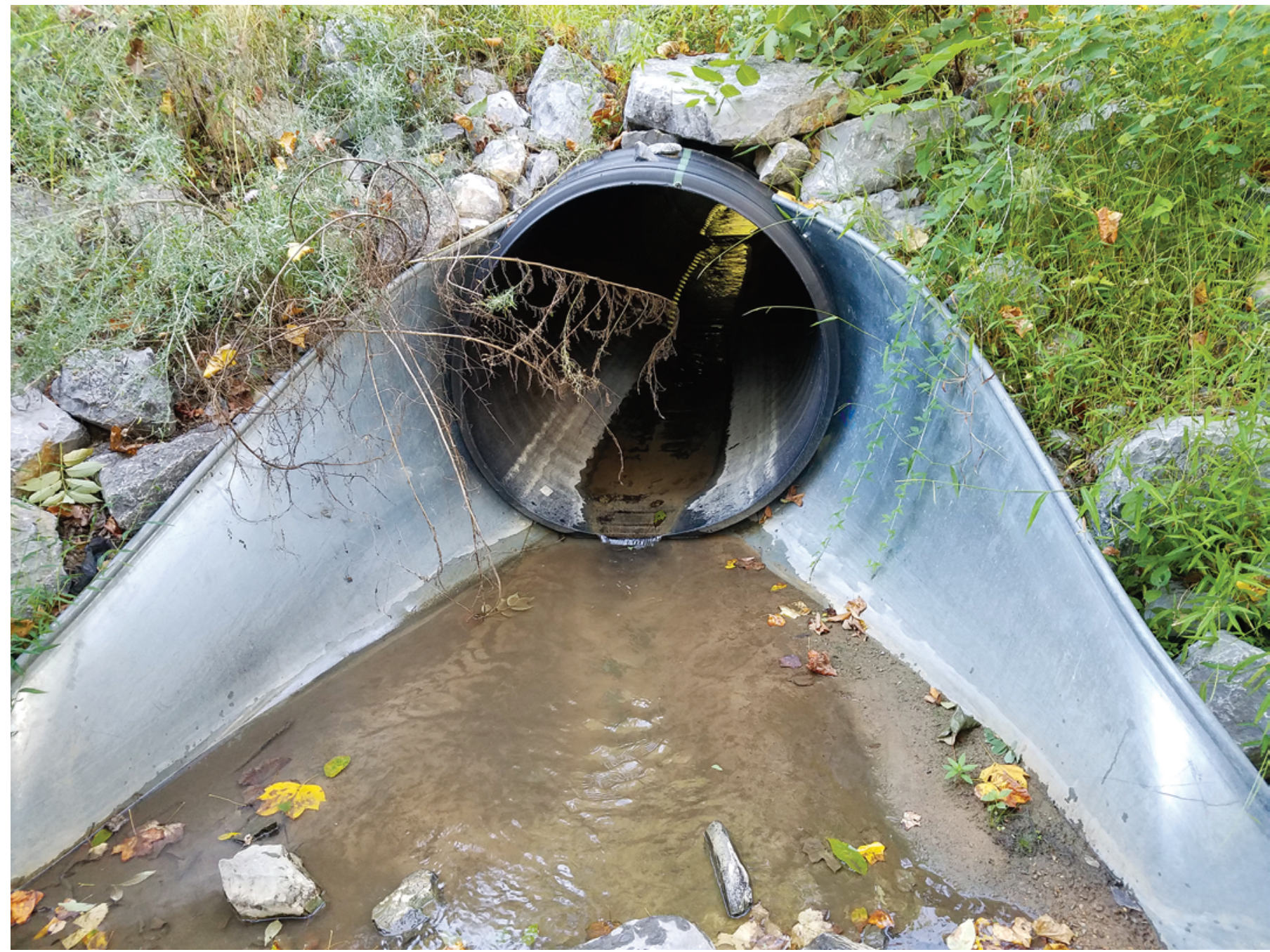

Figure 5. Photo of surface-water site SW-U at the Ammonium Perchlorate Rocket Motor Destruction Facility at the Letterkenny Army Depot, Pennsylvania, September 13, 2016. 
Two storm-runoff sites were identified at the ARMD Facility. The two storm-runoff sites (ST-A and ST-B) drain parking areas and buildings (less than 1 acre in total surface area for either sampling site) associated with the facility (fig. 3). The storm-runoff sites were to be sampled the same day as the surface-water sites. Runoff from the parking areas and buildings drains to culverts that discharge to a retention basin (fig. 7). No runoff was evident in the culverts or the retention basin on any day that surface-water samples were collected. No sediment was evident in either the culverts (fig. 8) or the retention basin on the days when the surfacewater sites were sampled from September to December 2016. Surface-water samples were collected Sept. 15, Oct. 12, Nov. 7, and Dec. 5, 2016. Based on daily radar estimates and records at two National Oceanic and Atmospheric Administration weather stations near LEAD, there was no measurable precipitation from Sept. 13 through Sept. 15, 2016, and from Oct. 10 through Oct. 12, 2016. There was no precipitation during Nov. 7-8, 2016, but light precipitation did occur at the time of sample collection on Nov. 9, 2016. Approximately an inch of precipitation fell during Dec. 5-6, 2016, prior to sampling on Dec. 7, 2016 (National Oceanic and Atmospheric Administration, 2018a and 2018b). There was no evidence of any sediment transport from the areas around the ARMD Facility to the culverts, and subsequently the retention basin, during the entire baseline characterization period (Sept. to Dec. 2016). The culverts and retention basin showed no signs of any sediment deposition; however, it is likely that small amounts of suspended sediment were transported via surface runoff through the culverts.

Nine soil sampling sites (SO-1 to SO-9) were identified in and around the ARMD Facility (table 4 and fig. 3). Soil sampling sites SO-1, SO-2, SO-3, SO-4 (fig. 9), SO-7, and SO-8 were either along a fence line or in an open-field setting. Soil sampling sites SO-5 (fig. 10), SO-6, and SO-9 were initially sited in parking areas at the time environmental monitoring began but were not suitable for soil sampling. SO-6 and SO-9 were moved to the nearest area where a representative soil sample could be collected. Soil site SO-5 was not near any other suitable location, so soil samples were collected below

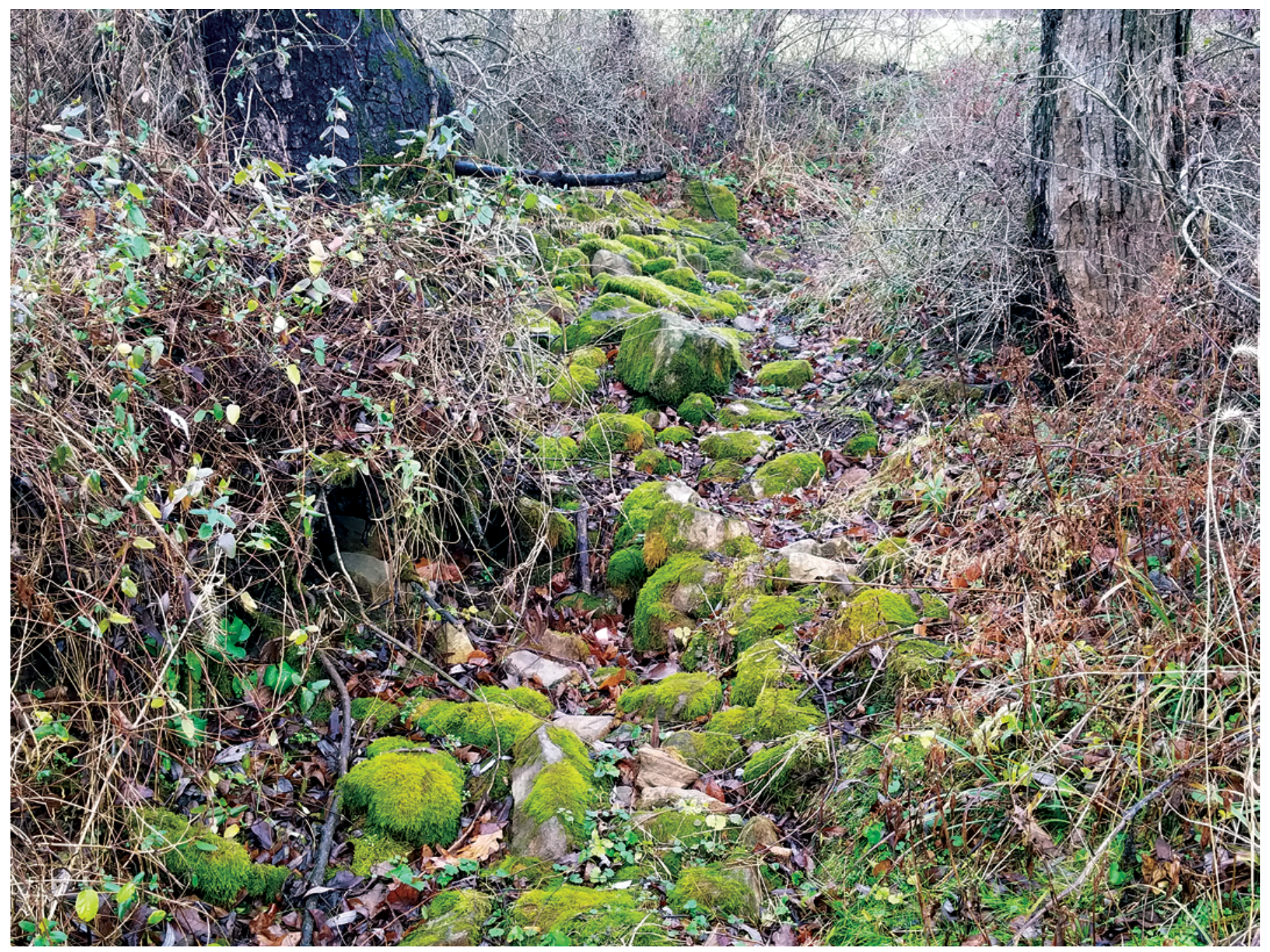

Figure 6. Photo of dry conditions at surface-water site SW-1D taken at the Ammonium Perchlorate Rocket Motor Destruction Facility at the Letterkenny Army Depot, Pennsylvania, December 7, 2016. 


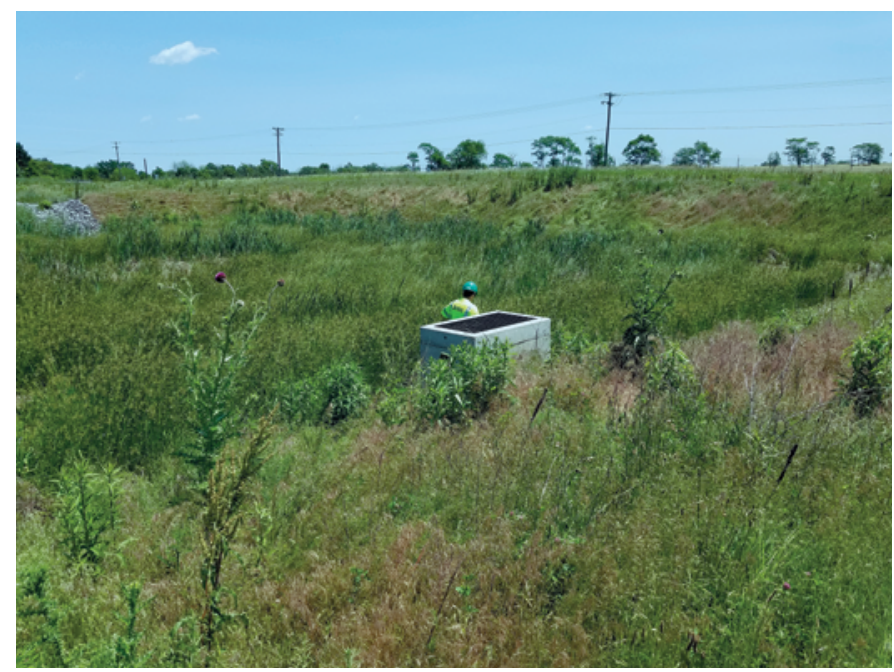

Figure 7. Photo of a retention basin that captures runoff water from areas adjacent to the Ammonium Perchlorate Rocket Motor Destruction Facility at the Letterkenny Army Depot, Pennsylvania, June 9, 2016.

the shale layer that had been deposited to support vehicle loads.

Soil samples were collected to a depth of approximately 6 inches. A stainless-steel trowel was used to remove the top organic layer with roots and vegetation. After removing the top organic layer, subsamples were collected with the trowel for all constituents except VOCs. The sample area ranged from 2 to 12 square feet per soil site, and the number of subsamples ranged from 5 to 12 per soil site. Subsamples were placed on a plastic sheet, mixed, and then placed in the sample jars using the trowel. Any rocks that were gravel size or larger were removed from the subsamples before the soil was placed in four glass jars (two 8-ounce and two 16-ounce containers) using the sampling trowel. Soil samples for VOC analyses were collected with an En Core sampler instead of a trowel. En Core samplers (25-gram capacity) are constructed from an inert composite polymer and are easily sealed after extraction from soil profile, immediately becoming an air-tight transportation vessel. Three En Core samples were collected at each sample location for each sampling event. All soil samples were placed on ice immediately after sample collection and delivered to the ALS laboratory in Middletown, $\mathrm{Pa}$., the day of sample collection.

\section{Quality Assurance and Quality Control}

QA/QC samples were collected for each sampling event and sample media. USGS personnel submitted replicate and blank samples for groundwater and surface-water samples for analysis; only replicate samples were submitted for soil samples. ALS laboratory also analyzed matrix-spike and matrix-spike duplicate (MS/MSD) samples for all sampling events and sample media. Three types of blank samples were analyzed at ALS laboratory: equipment, trip, and internal

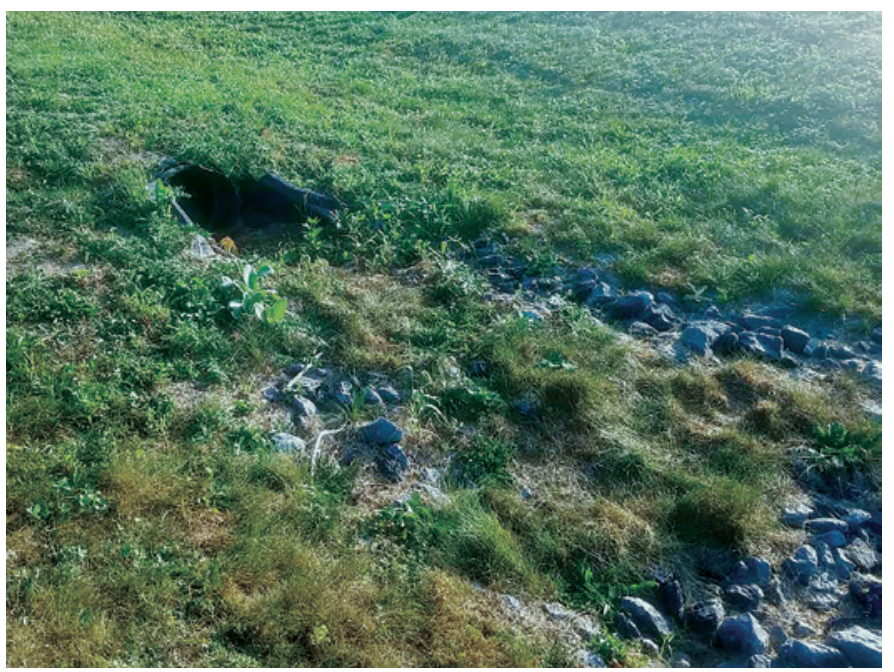

Figure 8. Photo of a culvert at storm-runoff site ST-B at the Ammonium Perchlorate Rocket Motor Destruction Facility at the Letterkenny Army Depot, Pennsylvania, September 27, 2016.

laboratory. An equipment blank is used to determine potential contamination from equipment and supplies (Francy and others, 1998). Trip blanks were prepared by ALS laboratory and shipped to USGS with the sample bottles provided by ALS laboratory. The trip blank was placed in a cooler the morning of sampling and was returned to ALS laboratory when samples were delivered later that day. The purpose of a trip blank is to identify VOC contaminants introduced into samples during transit to and from the laboratory. Internal laboratory blanks are used to quantify any laboratory bias from contamination. Replicate samples are used to determine the precision and variability of sample collection and processing (Francy and others, 1998). Matrix-spike and matrix-spike duplicate (MS/MSD) samples are environmental samples spiked in the laboratory to verify percent recoveries. MS/MSD samples are primarily used to check sample matrix interferences. MS/MSD samples that fall outside the acceptable range for a constituent could indicate a negative (recovering less than the acceptable range) or positive (recovery greater than the acceptable range) bias. All QA/QC data for this study are available online at https://doi.org/10.5066/P973YRPL.

\section{Groundwater}

Three trip blanks, one equipment blank, and multiple internal blanks were analyzed for groundwater samples. The trip blank submitted Oct. 11, 2016, was the only trip blank associated with groundwater samples that had any detectable VOC concentrations. Fifty-three VOCs were analyzed in each groundwater sample. Acetone and bromomethane were detected at concentrations of 5.2 and 0.40 micrograms per liter $(\mu \mathrm{g} / \mathrm{L})$, respectively, in the Oct. 11, 2016, trip blank. The Reporting Detection Levels (RDLs) for acetone and bromomethane were 10 and $1.0 \mu \mathrm{g} / \mathrm{L}$, respectively, so both 
Table 4. Descriptions of nine soil sampling sites at the Ammonium Perchlorate Rocket Motor Destruction Facility at the Letterkenny Army Depot, Pennsylvania, 2016.

\begin{tabular}{lcccc}
\hline Station identifier & Local name & $\begin{array}{c}\text { Latitude, } \\
\text { in decimal degrees }\end{array}$ & $\begin{array}{c}\text { Longitude, } \\
\text { in decimal degrees }\end{array}$ & Description \\
\hline 400100077442701 & SO-1 & 40.01671 & 77.74086 & Fence line, typical A horizon \\
\hline 400060077443201 & SO-2 & 40.01654 & 77.74211 & Fence line, typical A horizon \\
\hline 400054077443201 & SO-3 & 40.015 & 77.74229 & Fence line, typical A horizon \\
\hline 400056077442601 & SO-4 & 40.01555 & 77.74046 & Open field, typical A horizon \\
\hline 400058077442701 & SO-5 & 40.01618 & 77.74087 & Paved area, compact shale layer at surface \\
\hline 400059077442901 & SO-6 & 40.01628 & 77.74139 & Paved area, compact shale layer at surface \\
\hline 400057077442701 & SO-7 & 40.0158 & 77.74091 & Open field, typical A horizon \\
\hline 400055077442901 & SO-8 & 40.01541 & 77.74152 & Open field, typical A horizon \\
\hline 400055077443101 & SO-9 & 40.01531 & 77.74207 & Paved area, compact shale layer at surface \\
\hline
\end{tabular}

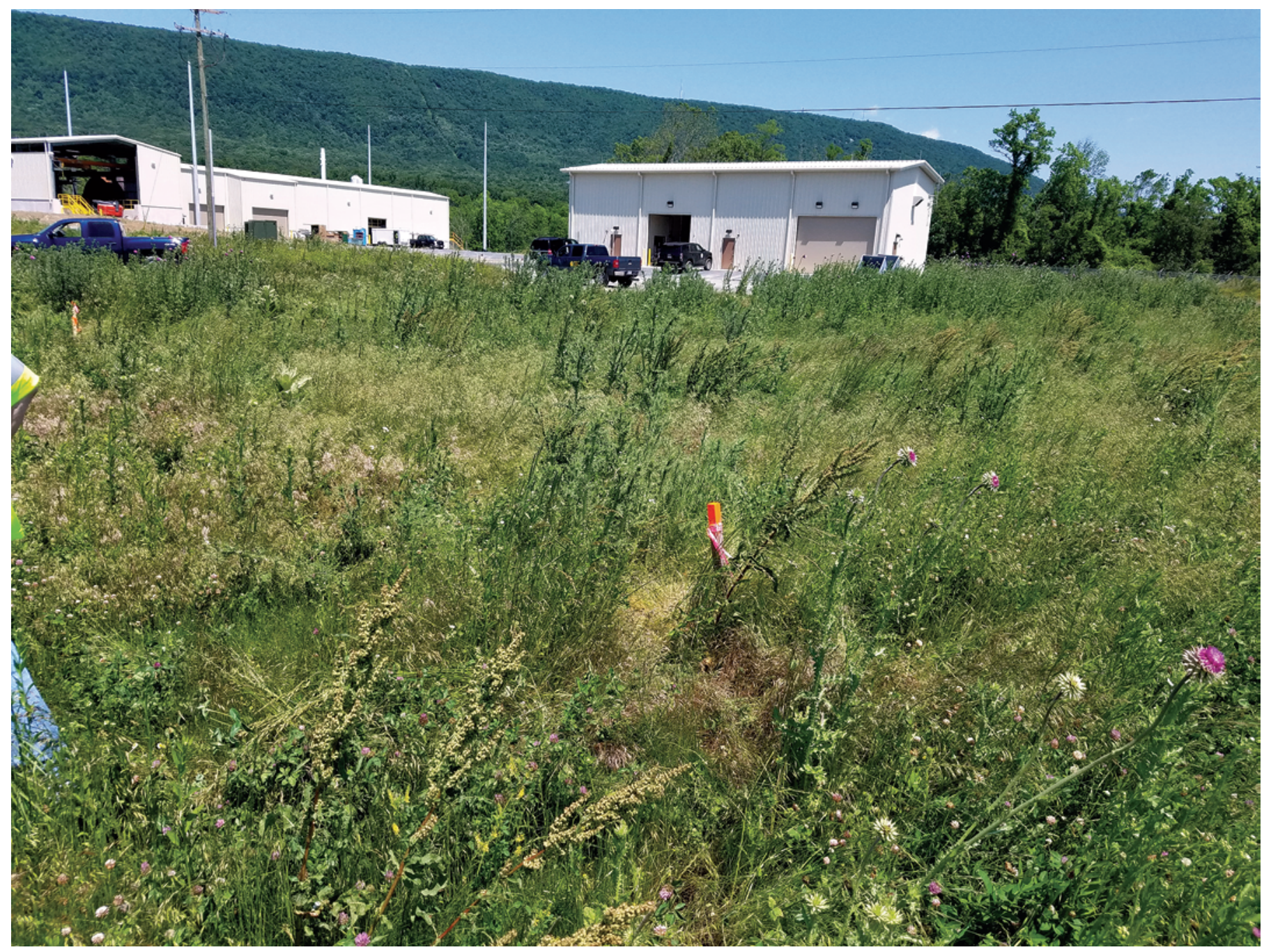

Figure 9. Photo of soil sampling site SO-4 at the Ammonium Perchlorate Rocket Motor Destruction Facility at the Letterkenny Army Depot, Pennsylvania, June 9, 2016. 


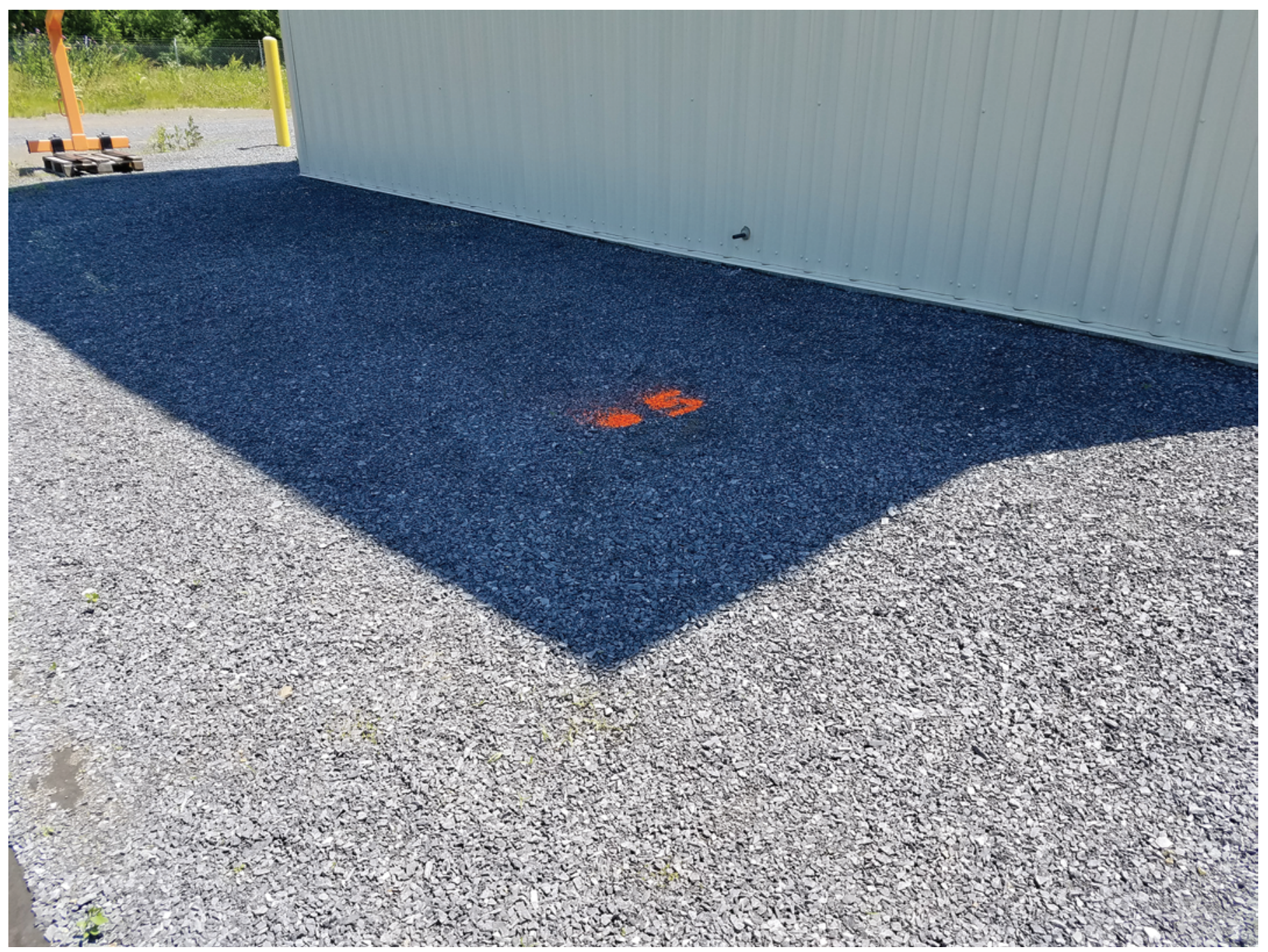

Figure 10. Photo of soil sampling site SO-5 at the Ammonium Perchlorate Rocket Motor Destruction Facility at the Letterkenny Army Depot, Pennsylvania, June 9, 2016.

were flagged as estimated values. Four other constituents were detected at less than their respective RDLs in the equipment blank submitted Dec. 5, 2016: chloride $(\mathrm{Cl} ; 0.18$ milligrams per liter $[\mathrm{mg} / \mathrm{L}])$, bromomethane $(0.50 \mu \mathrm{g} / \mathrm{L})$, acetone $(5.8 \mu \mathrm{g} / \mathrm{L})$, and chloromethane $(0.55 \mu \mathrm{g} / \mathrm{L})$. Internal blanks for groundwater were analyzed by ALS laboratory; concentrations of seven constituents were detected at less than the RDLs. Total $\mathrm{Cl}$ was detected consistently in internal blanks analyzed from October to December 2016. Nineteen internal blanks were analyzed for total $\mathrm{Cl}$ by ALS laboratory from October to December 2016; Cl was detected in each blank (values ranged from 0.20 to $0.33 \mathrm{mg} / \mathrm{L}$ ). Total sulfate was detected in only four internal blanks analyzed during October 2016 at $0.07-0.08 \mathrm{mg} / \mathrm{L}$. Trichloromethane (also known as chloroform; 0.24, 0.29, and $0.57 \mu \mathrm{g} / \mathrm{L}$ ) and total phosphorus (P; 0.014 and $0.019 \mathrm{mg} / \mathrm{L}$ ) were detected in internal blanks analyzed in September and November 2016. Chloromethane was detected $(0.50$ and $0.43 \mu \mathrm{g} / \mathrm{L})$ in internal blanks analyzed in November and December 2016. Bromomethane was detected $(0.41$ and $0.65 \mu \mathrm{g} / \mathrm{L})$ in internal blanks analyzed in
October and December 2016. Dichloromethane was detected only at $0.54 \mu \mathrm{g} / \mathrm{L}$ in the internal blank analyzed in October 2016.

Five replicate samples from groundwater wells were submitted for analyses from September to December 2016. Three of the replicate samples had one or more constituents with a relative percent difference (RPD) greater than 10 (table 5). Most of the RPDs were less than 5 percent. VOC results for replicate samples are not presented in table 5 because most VOC results were nondetects. There were five results for VOCs ( 3 for acetone and 1 each for chloromethane and bromomethane) in the paired routinereplicate samples in which one pair had a nondetect and the other had a detection of less than the RDL. These results indicate that replication of groundwater samples can be conducted with fairly good precision.

MS/MSD samples were analyzed by ALS laboratory for each groundwater sampling event. The only inorganic constituent to fall outside the acceptable range for groundwater MS/MSD samples was silicon dioxide $\left(\mathrm{SiO}_{2}\right)$. The 
Table 5. Relative percent differences for selected constituents between routine and replicate groundwater samples from four wells at the Ammonium Perchlorate Rocket Motor Destruction Facility at the Letterkenny Army Depot, Pennsylvania, 2016.

[Green shading denotes relative percent difference above 10 percent; NA, not applicable]

\begin{tabular}{|c|c|c|c|c|c|}
\hline \multirow{2}{*}{$\begin{array}{c}\text { Selected } \\
\text { constituent }\end{array}$} & \multicolumn{5}{|c|}{ Well and sample collection date } \\
\hline & $\begin{array}{c}\text { MW-1 } \\
\text { September 13, } 2016\end{array}$ & $\begin{array}{c}\text { MW-2 } \\
\text { October 11, } 2016\end{array}$ & $\begin{array}{c}\text { MW-3 } \\
\text { November 7, } 2016\end{array}$ & $\begin{array}{c}\text { MW-1 } \\
\text { November 7, } 2016\end{array}$ & $\begin{array}{c}\text { MW-4 } \\
\text { December 5, } 2016\end{array}$ \\
\hline Acidity & 2.70 & 4.35 & 0.00 & 0.00 & 18.18 \\
\hline Chloride & 0.00 & 0.00 & 0.00 & 2.60 & 0.00 \\
\hline Sulfate & 1.29 & 0.00 & 0.77 & 0.00 & 0.00 \\
\hline Nitrate plus nitrite & 0.00 & 0.00 & 0.00 & 0.00 & 0.00 \\
\hline Phosphorus & 7.41 & 5.26 & $\mathrm{NA}^{1}$ & 4.88 & 4.88 \\
\hline Dissolved aluminum & 0.00 & 0.00 & 0.00 & 0.00 & 0.00 \\
\hline Dissolved chromium & 0.00 & 17.50 & 5.71 & 9.76 & 9.76 \\
\hline Dissolved copper & 0.00 & 0.00 & 0.00 & 0.00 & 0.00 \\
\hline Dissolved iron & 0.00 & 0.00 & 0.00 & 0.00 & 0.00 \\
\hline Dissolved lead & 0.00 & 0.00 & 0.00 & 0.00 & 0.00 \\
\hline Dissolved mercury & 0.00 & 0.00 & 0.00 & 0.00 & 0.00 \\
\hline Dissolved molybdenum & 13.64 & 50.00 & 0.00 & 0.00 & 0.00 \\
\hline Dissolved silver & 0.00 & 0.00 & 0.00 & 0.00 & 0.00 \\
\hline Dissolved tin & 0.00 & 0.00 & 0.00 & 0.00 & 0.00 \\
\hline Dissolved zirconium & 0.00 & 0.00 & 0.00 & 0.00 & 0.00 \\
\hline
\end{tabular}

${ }^{1}$ Regular sample had estimated value of 0.071 milligrams per liter $(\mathrm{mg} / \mathrm{L})$ (below the reporting detection level of $0.1 \mathrm{mg} / \mathrm{L}$ ). The replicate value was less than $0.1 \mathrm{mg} / \mathrm{L}$.

acceptable MS/MSD recovery range for dissolved $\mathrm{SiO}_{2}$ was 75-125 percent. The MS/MSD recoveries for the Sept. 2016 and Nov. 2016 samples were 27-30 and 230-300 percent, respectively.

Results for nine VOCs fell outside the acceptable MS/MSD recovery range for at least one groundwater MS/MSD sample. Both 1,1,2-trichloro-1,2,2-trifluoroethane (also known as freon-113) and 1,2,3-trichlorobenzene had four MS/MSD samples (of eight total MS/MSD samples) with percent recoveries outside the acceptable range. The acceptable ranges for 1,1,2-trichloro-1,2,2-trifluoroethane and 1,2,3-trichlorobenzene were 50-130 and 61-126 percent, respectively. MS/MSD recoveries of 1,1,2-trichloro-1,2,2trifluoroethane from Oct. to Dec. 2016 were 131-159 percent for samples outside the acceptable range. MS/MSD results for 1,2,3-trichlorobenzene ranged from 40.2 to 49.9 percent for samples outside the acceptable recovery range that were internally analyzed at ALS laboratory from Sept. to
Nov. 2016. Three MS/MSD samples for 1,1-dichloroethene had values greater than the acceptable high recovery rate of 128 percent; percent recoveries for these Oct. and Dec. 2016 samples ranged from 133 to 137 percent. Four constituents (1,2,4-trichlorobenzene, carbon disulfide, cyclohexane, and trichlorofluoromethane) each had two MS/MSD results outside the acceptable ranges. Two MS/MSD samples for 1,2,4-trichlorobenzene had values (63.5 percent in Sept. 2016 and 63.9 percent in Nov. 2016) of less than the acceptable low recovery rate of 67 percent. Carbon disulfide, trichlorofluoromethane, and cyclohexane, each had two MS/MSD samples with values greater than the acceptable high recovery rates. The acceptable high-end recovery rates for carbon disulfide, trichlorofluoromethane, and cyclohexane were 131, 123, and 130 percent, respectively. These MS/MSD samples for carbon disulfide (132 percent recovery for two samples) and trichlorofluoromethane (138 and 133 percent recoveries) were analyzed in Oct. 2016. The 
high-end exceedances for cyclohexane (136 and 140 percent recoveries) were for MS/MSD samples analyzed in Nov. 2016. Trans-1,2-dichloroethene and tribromomethane (also called bromoform) in one MS/MSD sample each were outside the acceptable ranges. Trans-1,2-dichloroethene in one MS/MSD sample in Oct. 2016 exceeded the acceptable high-end value (122 percent) by 1 percent; in contrast, tribromomethane, in one MS/MSD sample in Sept. 2016 was less than the acceptable low-end value (70 percent) by 3.5 percent. All QA/QC data for this report are available online at https://doi. org/10.5066/P973YRPL.

\section{Surface Water}

Blank samples submitted for surface water QA/QC included 3 trip blanks, 1 equipment blank, and multiple internal blanks. Acetone was detected at an estimated value of $6.6 \mu \mathrm{g} / \mathrm{L}(\mathrm{RDL}=10 \mu \mathrm{g} / \mathrm{L})$ in the trip blank submitted on Oct. 12, 2016. Five VOCs were detected at concentrations less than the RDLs in the trip blank submitted on Nov. 9, 2016: 1,4-dichlorobenzene $(0.28 \mu \mathrm{g} / \mathrm{L}$, $\mathrm{RDL}=1 \mu \mathrm{g} / \mathrm{L})$, bromomethane $(0.45 \mu \mathrm{g} / \mathrm{L}, \mathrm{RDL}=1 \mu \mathrm{g} / \mathrm{L})$, 1,2,4-trichlorobenzene $(0.86 \mu \mathrm{g} / \mathrm{L}, \mathrm{RDL}=2 \mu \mathrm{g} / \mathrm{L})$, acetone $(3.6 \mu \mathrm{g} / \mathrm{L}, \mathrm{RDL}=10 \mu \mathrm{g} / \mathrm{L})$, and chloromethane $(0.45 \mu \mathrm{g} / \mathrm{L}$, $\mathrm{RDL}=1 \mu \mathrm{g} / \mathrm{L})$. Four constituents were detected at less than their respective RDLs in the equipment blank submitted Dec. 7, 2016: total $\mathrm{Cl}(0.49 \mathrm{mg} / \mathrm{L})$, dissolved iron (Fe; $22 \mu \mathrm{g} / \mathrm{L})$, dissolved molybdenum $(1.7 \mu \mathrm{g} / \mathrm{L})$, and bromomethane $(0.69 \mu \mathrm{g} / \mathrm{L})$. Note that for all the groundwater and surface-water samples collected from Sept. to Dec. 2016, hydrochloric acid $(\mathrm{HCl})$ was added by ALS laboratory at the time the bottles were prepared for shipment to the USGS office in New Cumberland, Pa.; subsequently, the $\mathrm{HCl}$ added by ALS remained in the sample bottle until sample collection. It was brought to the attention of USGS by another laboratory that $\mathrm{HCl}$ can interact with a bottle septum and release VOCs, primarily acetone (Ray Martrano, Seewald Laboratories, oral commun., 2017). The problem was corrected for water samples collected after December 2016 by adding $\mathrm{HCl}$ at the time of VOC sample collection.

In internal blanks submitted for surface water and analyzed by ALS laboratory, numerous constituents were detected, all at less than the RDLs. Eight VOCs were detected in internal blank samples during the baseline characterization period, Sept.-Dec. 2016. Trichloromethane was detected at concentrations ranging from 0.30 to $0.61 \mu \mathrm{g} / \mathrm{L}$ in internal blanks analyzed in Sept., Oct., and Dec. 2016. Bromomethane was detected in the Nov. 2016 internal blank $(0.51 \mu \mathrm{g} / \mathrm{L})$ and Dec. $2016(0.66 \mu \mathrm{g} / \mathrm{L})$. Carbon disulfide $(0.33 \mu \mathrm{g} / \mathrm{L})$, chloromethane $(0.40 \mu \mathrm{g} / \mathrm{L}), 1,3$-dichlorobenzene $(0.27 \mu \mathrm{g} / \mathrm{L})$, 1,4-dichlorobenzene $(0.32 \mu \mathrm{g} / \mathrm{L})$, and 1,2,4-trichlorobenzene $(0.83 \mu \mathrm{g} / \mathrm{L})$ were detected in the Nov. 2016 internal blank, and dichloromethane $(0.47 \mu \mathrm{g} / \mathrm{L})$ was detected in the Dec. 2016 internal blank. Four inorganic constituents were detected at concentrations less than the RDLs for internal blanks. Total $\mathrm{Cl}$ was detected at less than the RDL ( $1 \mathrm{mg} / \mathrm{L})$ in Oct., Nov., and Dec. 2016 blanks. ALS analyzed numerous blanks to verify the $\mathrm{Cl}$ results. $\mathrm{Cl}$ was detected in 4 blanks in Oct. 2016 at concentrations ranging from 0.19 to $0.27 \mathrm{mg} / \mathrm{L} ; 5$ blanks in Nov. 2016 at concentrations ranging from 0.25 to $0.29 \mathrm{mg} / \mathrm{L}$; and 8 blanks in Dec. 2016 at concentrations ranging from 0.23 to $0.36 \mathrm{mg} / \mathrm{L}$. The other inorganic constituents detected in internal samples were total $\mathrm{P}(0.033 \mathrm{mg} / \mathrm{L}$ in Nov. 2016), dissolved molybdenum (0.00069 mg/L in Dec. 2016), and dissolved selenium (Se; $0.0016 \mathrm{mg} / \mathrm{L}$ in Dec. 2016).

One replicate sample was collected in Oct. 2016. Concentrations of only eight constituents differed between the routine and replicate samples. Total $\mathrm{Cl}$, total nitrate plus nitrite, dissolved $\mathrm{SiO}_{2}$, dissolved barium (Ba), and dissolved chromium $(\mathrm{Cr})$ had RPDs of less than 5 percent between the routine and replicate samples. The three constituents with RPDs greater than 5 percent were perchlorate ( 9 percent), dissolved potassium (K; 12 percent), and fluoride (F; 29 percent). The measured concentrations of F were 0.04 and $0.06 \mathrm{mg} / \mathrm{L}$. No VOCs were detected in either the routine or replicate sample in Oct. 2016.

MS/MSD samples were analyzed by ALS laboratory for each surface-water sampling event, but most MS/MSD samples were analyzed in association with the Nov. 2016 surface-water sampling. The only two inorganic constituents to fall outside the acceptable range for a surface-water MS/MSD sample were dissolved $\mathrm{SiO}_{2}$ and $\mathrm{Se}$. The acceptable MS/MSD recovery range for both constituents was $75-125$ percent. The MS/MSD recoveries for dissolved $\mathrm{SiO}_{2}$ in two Nov. 2016 samples were 223 and 220 percent. The MS/MSD recoveries for dissolved Se in two Nov. 2016 samples were 129 and 130 percent.

MS/MSD sample results from ALS laboratory for VOCs were provided only for the Nov. 2016 samples. Three VOCs fell outside the acceptable MS/MSD recovery range for at least one surface-water MS/MSD sample. Two MS/MSD samples for 1,1,2-trichloro-1,2,2-trifluoroethane and methylcyclohexane had recoveries of 142 and 158 percent, respectively, which are greater than the acceptable high end of 130 percent for both VOCs. Two MS/MSD samples for chloroethane had recoveries of 46 and 49 percent, which are less than the acceptable low end of 51 percent recovery.

\section{Soil}

Only internal laboratory blanks were analyzed in coordination with soil samples. Internal blanks for soil samples were analyzed by ALS laboratory for each soil sampling event. $\mathrm{Cl}$ was detected in each blank analyzed for soil samples at concentrations much less than the RDL of 50 milligrams per kilogram $(\mathrm{mg} / \mathrm{kg})$. The range of total $\mathrm{Cl}$ concentrations in internal blanks was 1.6 to $5.3 \mathrm{mg} / \mathrm{kg}$. F and sulfate $\left(\mathrm{SO}_{4}\right)$ were detected at less than the RDLs in blanks submitted for Sept.-Nov. 2016 samples; concentrations ranged from 0.3 to $0.6 \mathrm{mg} / \mathrm{kg}$ and 13.6 to $18.0 \mathrm{mg} / \mathrm{kg}$, respectively. The RDLs for $\mathrm{F}$ and $\mathrm{SO}_{4}$ were 1.0 and $50 \mathrm{mg} / \mathrm{kg}$, respectively. P was detected in two internal blanks submitted in Sept. and Nov. 2016 
at concentrations of 0.92 and $4.1 \mathrm{mg} / \mathrm{kg}$, respectively. The RDLs for P in Sept. and Nov. 2016 were 2.5 and $9.7 \mathrm{mg} / \mathrm{kg}$, respectively.

Only two constituents had internal blank results that exceeded RDLs. Dichloromethane $(\mathrm{RDL}=2$ micrograms per kilogram $[\mu \mathrm{g} / \mathrm{kg}])$ was detected at concentrations of 4.5 and $2.5 \mu \mathrm{g} / \mathrm{kg}$ in blanks submitted for analysis in Sept. and Nov. 2016 , respectively. Sulfur $(\mathrm{RDL}=10 \mu \mathrm{g} / \mathrm{kg}$ ) was detected at $10.4 \mu \mathrm{g} / \mathrm{kg}$ in the internal blank submitted in Nov. 2016.

Four replicate soil samples were submitted for analyses from Sept. to Dec. 2016. Replicate data show higher variability for soil samples than for water samples collected for this study. Replicate variability for the Oct. 2016 soil samples was less than the variability detected in other months (table 6). Only three VOCs were detected in the routine and replicate soil samples. Perchlorate, silver (Ag), and tin (Sn) were not detected in the routine and replicate samples. Most constituents listed in table 6 had RPDs greater than 20 percent. The constituents that showed the least amount of variability in replicate samples were total solids, $\mathrm{Cl}$, soil moisture, $\mathrm{Zr}$, and P. These constituents had a mean RPD between routine and replicate samples of less than 10 percent.

MS/MSD samples were analyzed by ALS laboratory for each soil sampling event. MS/MSD results show more laboratory bias for soil samples than for water samples collected for this study. Twelve inorganic constituents (out of 22 inorganic constituents) were outside the acceptable ranges for at least one MS/MSD soil sample analyzed from Sept. to Dec. 2016. Aluminum (Al), iron (Fe), and $\mathrm{SiO}_{2}$ in four MS/MSD samples had relative percent recoveries outside of the acceptable range of 75-125 percent. MS/MSD data for $\mathrm{Al}$ and Fe are available only for Sept. and Nov. 2016; both constituents

Table 6. Relative percent differences for selected constituents between routine and replicate soil samples collected at the Ammonium Perchlorate Rocket Motor Destruction Facility at the Letterkenny Army Depot, Pennsylvania, September-December 2016.

[NA, not applicable]

\begin{tabular}{|c|c|c|c|c|}
\hline \multirow{2}{*}{$\begin{array}{c}\text { Selected } \\
\text { constituent }\end{array}$} & \multicolumn{4}{|c|}{ Soil sampling site and sample collection date } \\
\hline & $\begin{array}{c}\text { S0-4 } \\
\text { September 14, } 2016\end{array}$ & $\begin{array}{c}\text { SO-2 } \\
\text { October 13, } 2016\end{array}$ & $\begin{array}{c}\text { SO-7 } \\
\text { November 8, } 2016\end{array}$ & $\begin{array}{c}\text { S0-9 } \\
\text { December 8, } 2016\end{array}$ \\
\hline Arsenic & 24.67 & 10.00 & 25.81 & 19.78 \\
\hline Barium & 24.80 & 2.88 & 26.42 & 45.84 \\
\hline Chloride & 5.16 & 3.65 & 9.35 & 0.00 \\
\hline Chromium & 28.04 & 7.69 & 35.46 & 39.23 \\
\hline Copper & 23.86 & 7.14 & 28.57 & 31.81 \\
\hline Dichloromethane & 7.04 & 86.96 & 41.51 & 19.88 \\
\hline Mercury & 5.99 & 13.45 & 7.33 & 29.31 \\
\hline Methyl tert-butyl ether & 16.67 & NA & NA & 5.56 \\
\hline Molybdenum & 22.81 & 3.85 & 28.91 & 29.79 \\
\hline Nitrate plus nitrite as nitrogen & NA & NA & 69.88 & NA \\
\hline Phosphorus & 11.64 & 2.74 & 0.56 & 24.49 \\
\hline Potassium & 35.01 & 7.10 & 50.84 & 44.96 \\
\hline Selenium & 21.59 & NA & 26.92 & 36.62 \\
\hline Silica & 37.30 & 1.49 & 4.11 & 22.14 \\
\hline Soil moisture & 1.31 & 0.00 & 7.09 & 11.74 \\
\hline
\end{tabular}

${ }^{1}$ If either the regular or replicate sample was a nondetection (less than value), then a relative percent difference could not be determined. 
had 2 samples at much less than and 2 samples at much greater than the acceptable range limits. For $\mathrm{SiO}_{2}, 3 \mathrm{MS} / \mathrm{MSD}$ samples were less than the acceptable lower end, and 1 sample was greater than the acceptable high end from a total of $8 \mathrm{MS} / \mathrm{MSD}$ samples analyzed from Sept. to Nov. 2016. For copper $(\mathrm{Cu}), \mathrm{Cr}$, and $\mathrm{Zr}$, three MS/MSD samples were outside of the acceptable recovery range of 75-125 percent. Relative percent recoveries for $\mathrm{Cu}, \mathrm{Cr}$, and $\mathrm{Zr}$ were 68-210, 63-157, and 21-109 percent, respectively. Other inorganic constituents with one or two MS/MSD samples outside relative percent recovery ranges were arsenic (As), $\mathrm{Ba}, \mathrm{F}$, lead $(\mathrm{Pb}), \mathrm{P}$, and $\mathrm{K}$.

Of the 53 VOCs analyzed, 39 were outside the acceptable relative recovery percent range for at least one soil MS/MSD sample (74 percent; appendix 2). Acceptable relative percent recoveries varied by VOC. Seven MS/MSD samples were analyzed internally at ALS laboratory for each VOC. All MS/MSD samples for methyl acetate collected from September to December 2016 had relative percent recoveries greater than the high end of the range of 130 percent (ranging from 132 to 267 percent). The relative percent recoveries for 1,2,3-trichlorobenzene, 1,2,4-trichlorobenzene, 1,3-dichlorobenzene, 1,4-dichlorobenzene, and trans-1,3-dichloropropene in six MS/MSD samples were less than the acceptable low end values. These VOCs were present in only one MS/MSD sample in the acceptable range for MS/MSD samples collected in either Nov. or Dec. 2016. The acceptable low-end recovery for 1,2,3-trichlorobenzene, 1,2,4-trichlorobenzene, 1,3-dichlorobenzene, 1,4-dichlorobenzene, and trans1,3-dichloropropene ranged from 63 to 77 percent. The range of percent recoveries below the acceptable low-end values for 1,2,3-trichlorobenzene, 1,2,4-trichlorobenzene, 1,3-dichlorobenzene, 1,4-dichlorobenzene, and trans-1,3-dichloropropene ranged from 18-62, 21-60, 34-71, 33-71, and 43-72 percent, respectively. Fourteen VOCs had 5 MS/MSD samples outside of acceptable ranges, with the 2 in-range samples for each analyzed in November 2016. An additional 20 VOCs had 1 to $4 \mathrm{MS} / \mathrm{MSD}$ samples that fell outside of the acceptable ranges (appendix 2; refer to Galeone (2019) at https://doi. org/10.5066/P973YRPL).

\section{Baseline Characterization Data}

The following sections characterize baseline data from samples that were collected monthly from September to December 2016 (baseline period prior to operation of the ARMD Facility) at 4 groundwater wells, 1 surface-water site, and 9 soil sites at the ARMD Facility.

\section{Groundwater}

Groundwater samples from the four monitoring wells around the ARMD Facility were collected monthly from Sept. to Dec. 2016. Static water levels prior to pumping the wells were fairly consistent from month to month (fig. 11 and appendix 1). The range of water levels measured at the time of sampling in any well did not exceed 2.3 feet. Sampled water was shallowest at MW-2 (average was 6.36 feet below land surface) and deepest at MW-3 (average was $29.83 \mathrm{ft}$ below land surface). Land-surface elevations relative to the NAVD 88 at MW-2 and MW-3 are 678.88 and 702.60 feet, respectively.

Field characteristic for the four wells were relatively consistent from Sept. to Dec. 2016. Dissolved oxygen for the wells was less than $3.0 \mathrm{mg} / \mathrm{L}$ in all samples collected. The $\mathrm{SC}$ measured at each well was stable from sample to sample, with the lowest mean SC measured at MW-1 $(220 \mu \mathrm{s} / \mathrm{cm})$ and highest at MW-3 $(771 \mu \mathrm{s} / \mathrm{cm})$. Mean $\mathrm{pH}$ ranged from 6.45 at MW-1 to 6.98 at MW-3 (fig. 11). All the wells were completed in the Martinsburg Formation; however, the western edge of the well field where MW-2 and MW-3 are sited is near the contact with the Martinsburg Formation (shale) and the Chambersburg Formation, which is composed of argilaceous limestone (fig. 2). The proximity to the limestone formation could contribute dissolved ions to the water that flows to MW-3. MW-3 had the highest SC followed by MW-2. MW-3 is 59 feet deeper than MW-2, and it is likely the flow path to MW-3 is in greater contact with the Chambersburg Formation than the more shallow MW-2. Water temperatures were highest in MW-2 (mean $\left.=14.7^{\circ} \mathrm{C}\right)$, with the other three wells having mean water temperatures ranging from 12.1 to $12.7^{\circ} \mathrm{C}$. The well depth of MW-2 is $22 \mathrm{ft}$; it's the shallowest well in the well network at the ARMD Facility (table 2).

Inorganic analytical results showed no inorganic constituents that exceeded any U.S. Environmental Protection Agency (EPA) Maximum Contaminant Levels (MCLs) (U.S. Environmental Protection Agency, 2009). Dissolved As was detected only in samples from two wells, MW-1 and MW-2, at mean concentrations of 2.8 and $5.2 \mu \mathrm{g} / \mathrm{L}$, respectively (fig. 12). The MCL for As is $10 \mu \mathrm{g} / \mathrm{L}$. Similar to some other constituents, some concentrations of dissolved As were less than nondetect values. This occurred because RDLs can vary by sample and by date. Values less than the RDL are considered to be estimated values; if no detection occurs, then the result is reported as "less than." Total nitrate was not detected in any groundwater sample (appendix 1) and had an RDL of $0.2 \mathrm{mg} / \mathrm{L}$. The maximum total phosphorus $(\mathrm{P})$ concentration in any groundwater sample was $0.15 \mathrm{mg} / \mathrm{L}$ for MW-1 (fig. 13). The deepest well, MW-3, had the lowest total P concentration of the four wells. Mean total $\mathrm{Cl}$ and total $\mathrm{SO}_{4}$ concentrations for MW-3 (56 and $86.8 \mathrm{mg} / \mathrm{L}$, respectively) were higher than for the other wells; the total $\mathrm{Cl}$ concentration in MW-3 was more than a magnitude greater than that of any other well. The higher concentrations of total $\mathrm{Cl}$ and total $\mathrm{SO}_{4}$ for MW-3 are reflected in the higher SC for this well. Higher dissolved ion concentrations typically are expected in deeper wells compared to more shallow wells completed in the same recharge area (Freeze and Cherry, 1979, p. 241).

Dissolved Fe was the only inorganic constituent measured at greater than a Secondary Maximum Contaminant Level (SMCL; fig. 12). All samples collected at MW-1, 

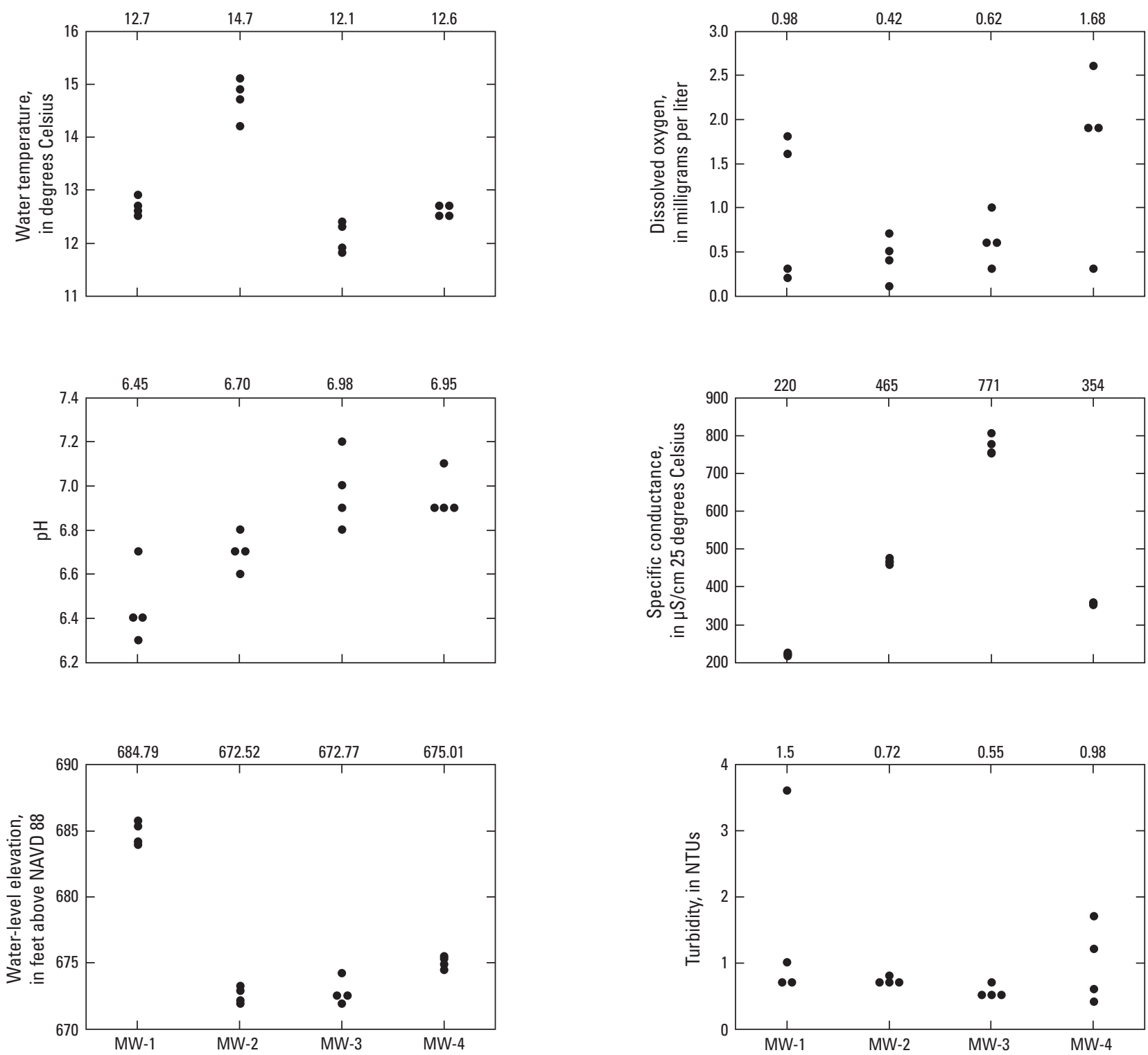

Figure 11. Measured and mean values of water temperature, dissolved oxygen, $\mathrm{pH}$, specific conductance, water level, and turbidity for water samples collected at the four monitoring wells at the Ammonium Perchlorate Rocket Motor Destruction Facility at the Letterkenny Army Depot, Pennsylvania, September-December 2016.

(Mean values are given above the graphs; $\mu \mathrm{S} / \mathrm{cm}$, microsiemens per centimeter; NTUs, Nephelometric Turbidity Units; NAVD 88, North American Vertical Datum of 1988)

MW-2, and MW-4 exceeded the SMCL for Fe of $300 \mu \mathrm{g} / \mathrm{L}$ (U.S. Environmental Protection Agency, 2009). Mean dissolved Fe concentrations for MW-1, MW-2, and MW-4 were $2,600,1,100$, and $1,300 \mu \mathrm{g} / \mathrm{L}$, respectively; in contrast, the mean dissolved Fe concentration for MW-3 was $100 \mu \mathrm{g} / \mathrm{L}$. Exceedance of the SMCL for Fe can cause discoloration of materials. No health effects are related to any SMCL exceedance. There were no detections in any of the ARMD groundwater samples of dissolved $\mathrm{Al}(\mathrm{RDL}=80 \mu \mathrm{g} / \mathrm{L})$, dissolved cadmium $(\mathrm{Cd})(\mathrm{RDL}=1 \mu \mathrm{g} / \mathrm{L})$, dissolved $\mathrm{Cu}(\mathrm{RDL}=5 \mu \mathrm{g} / \mathrm{L})$, dissolved $\mathrm{Pb}(\mathrm{RDL}=2 \mu \mathrm{g} / \mathrm{L})$, dissolved mercury $(\mathrm{Hg}$; $\mathrm{RDL}=0.5 \mu \mathrm{g} / \mathrm{L})$, dissolved $\mathrm{Ag}(\mathrm{RDL}=2 \mu \mathrm{g} / \mathrm{L})$, dissolved
$\mathrm{Sn}(\mathrm{RDL}=5 \mu \mathrm{g} / \mathrm{L})$, dissolved $\mathrm{Zr}(\mathrm{RDL}=10 \mu \mathrm{g} / \mathrm{L})$, or perchlorate $(\mathrm{RDL}=0.2 \mu \mathrm{g} / \mathrm{L})$ (appendix 1$)$.

Only three VOCs were detected in samples collected from the ARMD wells from October to December 2016. No VOCs were detected in Sept. 2016 samples, and only one VOC (bromomethane) was detected in an Oct. 2016 sample. Bromomethane was detected four times at less than the RDL of $1 \mu \mathrm{g} / \mathrm{L}$ at concentrations ranging from 0.41 to $0.67 \mu \mathrm{g} / \mathrm{L}$ (appendix 1). Bromomethane was detected at MW-2 in Oct. and Dec. 2016 and in MW-1 and MW-4 in Dec. 2016. Acetone was detected less than the RDL of $10 \mu \mathrm{g} / \mathrm{L}$ in two samples collected in Nov. 2016 from MW-2 $(3.4 \mu \mathrm{g} / \mathrm{L})$ and MW-4 $(5.4 \mu \mathrm{g} / \mathrm{L})$. Chloromethane was detected at less than 

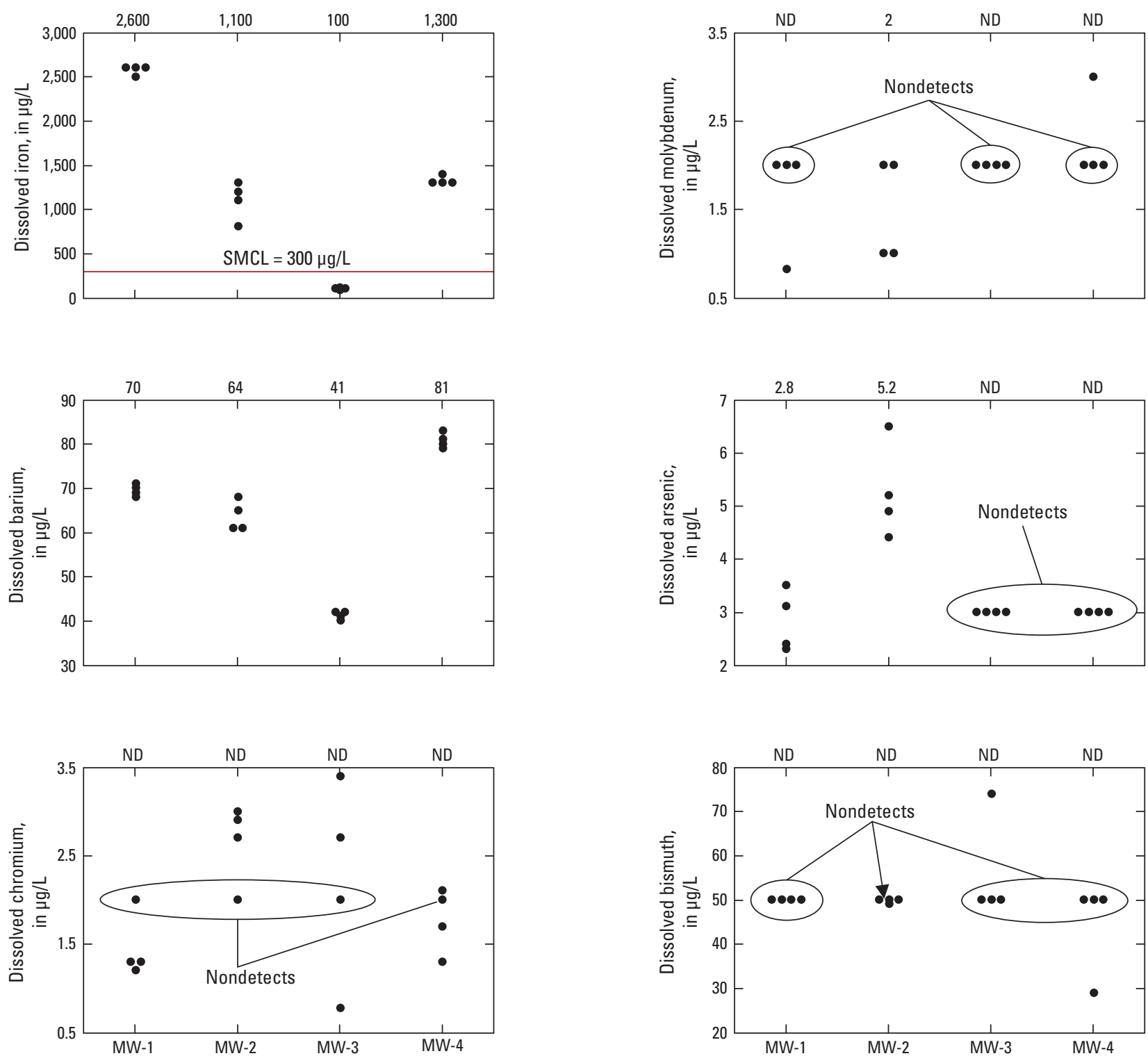

Figure 12. Measured and mean concentrations of dissolved iron, molybdenum, barium, arsenic, chromium, and bismuth in water samples collected from four monitoring wells at the Ammonium Perchlorate Rocket Motor Destruction Facility at the Letterkenny Army Depot, Pennsylvania, September-December 2016.

(Mean values are given above plot; ND, not determined; $\mu \mathrm{g} / \mathrm{L}$, micrograms per liter; SMCL, secondary maximum contaminant level)

the RDL of $1 \mu \mathrm{g} / \mathrm{L}$ in one sample collected in Nov. 2016 from MW-4 $(0.44 \mu \mathrm{g} / \mathrm{L})$ and one sample collected in Dec. 2016 from MW-2 $(0.46 \mu \mathrm{g} / \mathrm{L})$. Each of the VOCs detected in groundwater samples were also detected in blank samples. Bromomethane, acetone, and chloromethane were detected in blanks with values ranging from 0.40 to $0.65 \mu \mathrm{g} / \mathrm{L}, 5.2$ to $5.8 \mu \mathrm{g} / \mathrm{L}$, and 0.43 to $0.55 \mu \mathrm{g} / \mathrm{L}$, respectively.

\section{Surface Water}

Surface-water samples were collected at SW-U from September to December 2016. The downgradient streams did not have any flow on the days when SW-U was sampled, so there are no data for any of the upgradient surface-water sites. Therefore, the surface-water data collected during the baseline characterization period are only representative of the environment upgradient from the ARMD Facility. SW-U drains 0.44 square miles of forested land (fig. 14). The drainage basin extends to the top of Broad Mountain with an approximate elevation at the top of 2,250 feet above the NAVD 88. The elevation at SW-U is about 715 feet above the NAVD 88. This steep gradient limits recharge water interaction with the deeper groundwater system, and this is reflected in the field and analytical data for $\mathrm{SW}-\mathrm{U}$. Mean total $\mathrm{Cl}$ and total $\mathrm{SO}_{4}$ concentrations at SW-U were 1.8 and $8.4 \mathrm{mg} / \mathrm{L}$, respectively (table 7). These concentrations are evidence of relatively short flow paths through the shallow groundwater system (Freeze and 

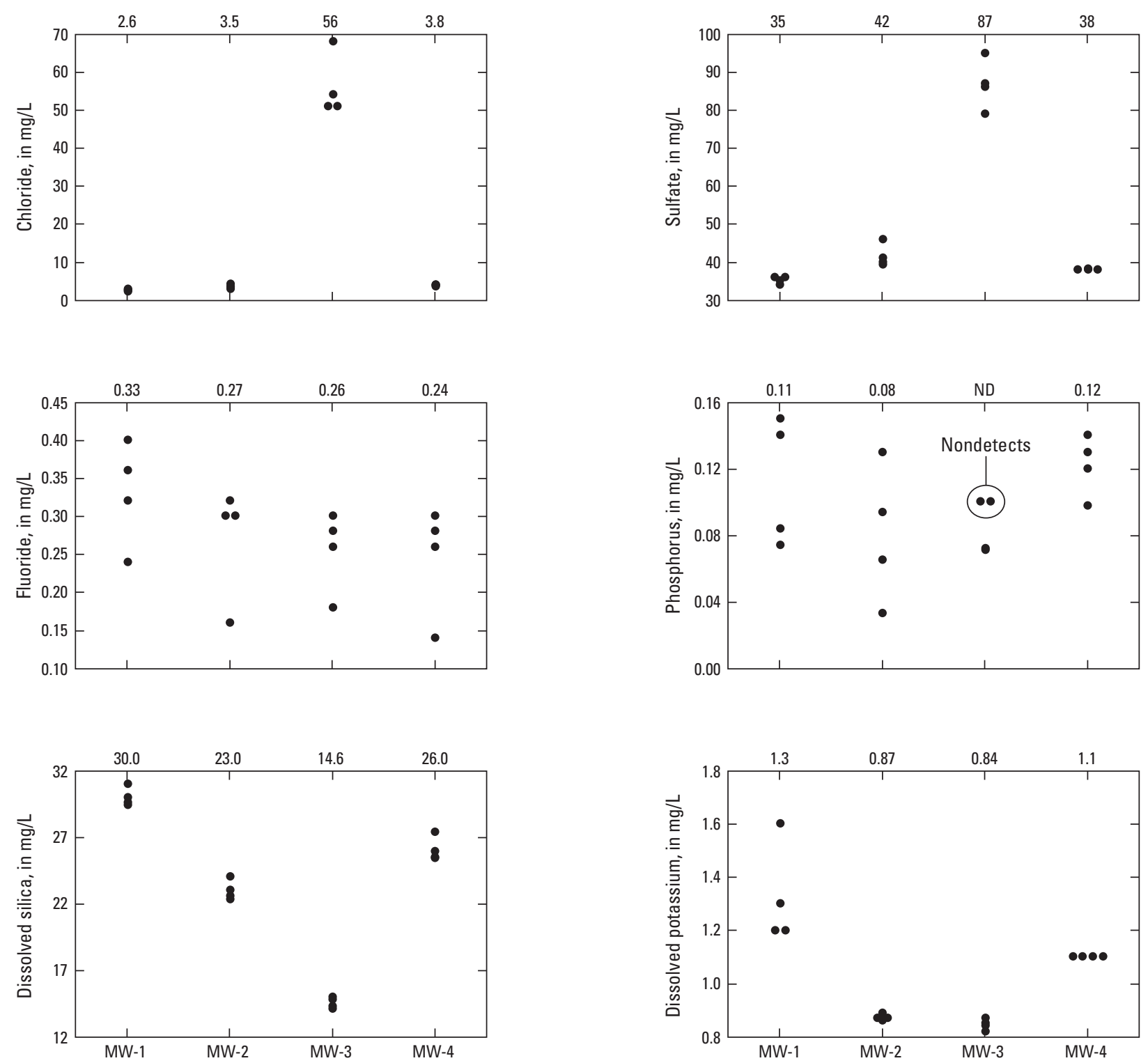

Figure 13. Measured and mean concentrations of chloride, sulfate, fluoride, phosphorus, dissolved silica, and dissolved potassium concentrations in water samples collected from four monitoring wells at the Ammonium Perchlorate Rocket Motor Destruction Facility at the Letterkenny Army Depot, Pennsylvania, September-December 2016.

(Mean values are given above plot; ND, not determined; $\mathrm{mg} / \mathrm{L}$, milligrams per liter)

Cherry, 1979, p. 241). Note that $\mathrm{Cl}$ was detected in QA/QC blank samples at a range of $0.19-0.36 \mathrm{mg} / \mathrm{L}$ for surface-water samples. The mean SC of $292 \mu \mathrm{S} / \mathrm{cm}$ is somewhat high for a small forested basin, but the underlying bedrock at SW-U is limestone of the St. Paul Group. This bedrock can contribute to the $\mathrm{SC}$ through dissolution of calcium and magnesium. The mean $\mathrm{pH}$ for samples collected at SW-U was 7.6, and this slightly alkaline $\mathrm{pH}$ is also reflective of the underlying limestone formation.

There were no apparent water-quality issues for the water sampled at SW-U. Samples were collected during base-flow conditions. No storm events were sampled. Stream discharge ranged from 0.03 to 0.08 cubic feet per second $\left(\mathrm{ft}^{3} / \mathrm{s}\right)$. The turbidity measured in Sept. 2016 was 23 nephelometric turbidity units (NTUs), but this sediment was grayish-white in color and not due to storm movement of soil particles. No total $\mathrm{P}$ was detected at an RDL equal to $0.10 \mathrm{mg} / \mathrm{L}$. The maximum total nitrate plus nitrite as $\mathrm{N}$ concentration detected was $0.20 \mathrm{mg} / \mathrm{L}$ (appendix 3). No MCLs or SMCLs were exceeded for any constituents. There were no detections in any of the dissolved forms of $\mathrm{Al}(\mathrm{RDL}=80 \mu \mathrm{g} / \mathrm{L})$, bismuth $(\mathrm{Bi}$; RDL $=$ $50 \mu \mathrm{g} / \mathrm{L}), \mathrm{Cd}(\mathrm{RDL}=1 \mu \mathrm{g} / \mathrm{L}), \mathrm{Cu}(\mathrm{RDL}=5 \mu \mathrm{g} / \mathrm{L}), \mathrm{Fe}(\mathrm{RDL}=$ $50 \mu \mathrm{g} / \mathrm{L}), \mathrm{Pb}(\mathrm{RDL}=2 \mu \mathrm{g} / \mathrm{L}), \mathrm{Hg}(\mathrm{RDL}=0.5 \mu \mathrm{g} / \mathrm{L}), \mathrm{Ag}(\mathrm{RDL}$ $=2 \mu \mathrm{g} / \mathrm{L}), \mathrm{Sn}(\mathrm{RDL}=5 \mu \mathrm{g} / \mathrm{L}), \mathrm{Zr}(\mathrm{RDL}=10 \mu \mathrm{g} / \mathrm{L})$, As $(\mathrm{RDL}$ $=3 \mu \mathrm{g} / \mathrm{L})$, and $\mathrm{Se}(\mathrm{RDL}=5 \mu \mathrm{g} / \mathrm{L})$.

VOCs were detected in the samples collected at SW-U in Nov. and Dec. 2016. All the VOC detections were less than the RDL. Bromomethane was detected in Nov. and Dec. at 


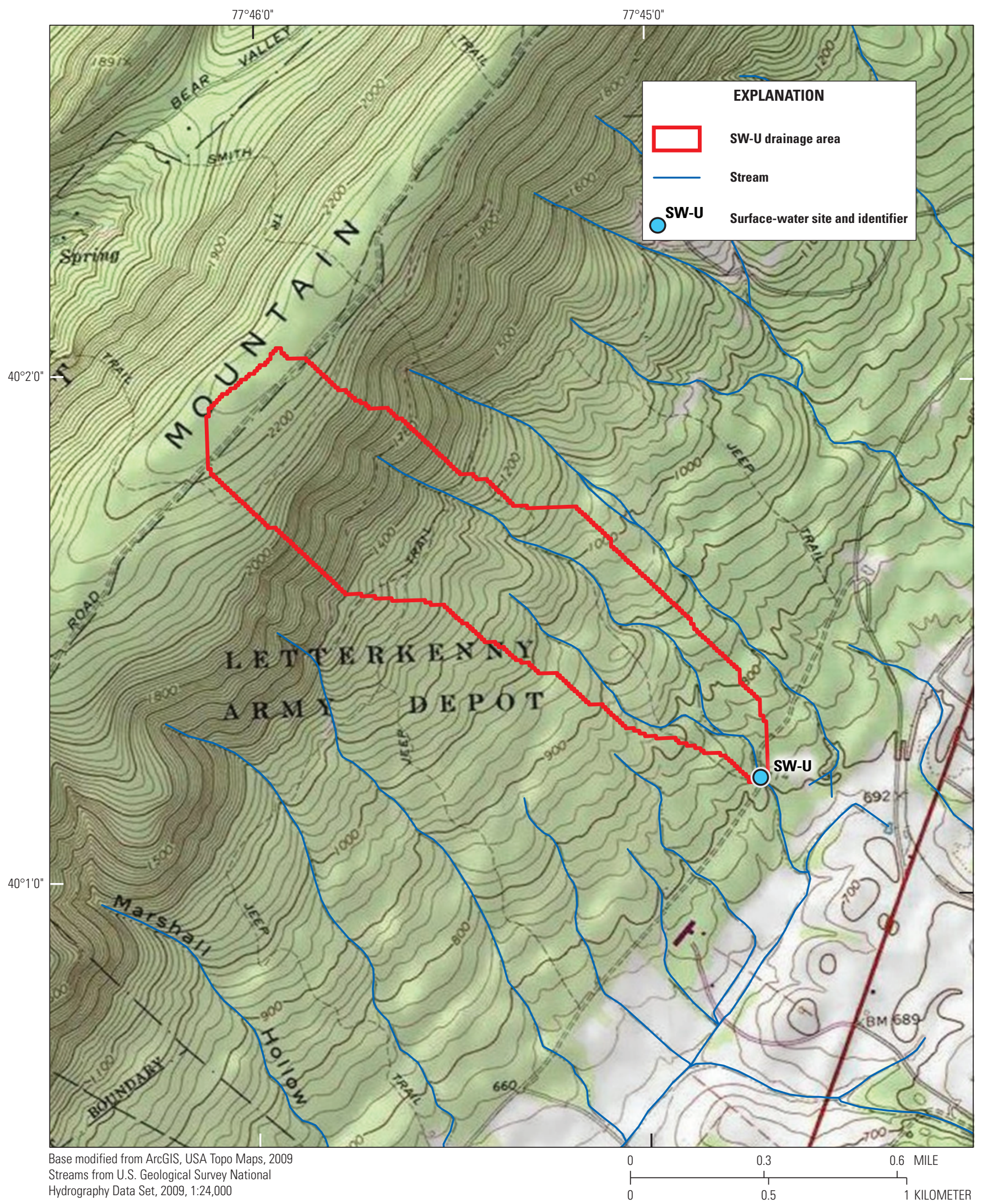

Figure 14. Drainage area for surface-water site SW-U at the Ammonium Perchlorate Rocket Motor Destruction Facility at the Letterkenny Army Depot, Pennsylvania, 2016. 
Table 7. Minimum, mean, and maximum values for selected constituents in surface-water samples collected at site SW-U near the Ammonium Perchlorate Rocket Motor Destruction Facility at the Letterkenny Army Depot, Pennsylvania, September-December 2016.

$\left[\mathrm{ft} / \mathrm{s}\right.$, cubic foot per second; $\mathrm{mg} / \mathrm{L}$, milligrams per liter; $\mu \mathrm{S} / \mathrm{cm}$, microsiemens per centimeter; ${ }^{\circ} \mathrm{C}$, degrees Celsius; NTU, Nephelometric Turbidity Units; $\mu \mathrm{g} / \mathrm{L}$, micrograms per liter; $<$, less than; ND, not determined]

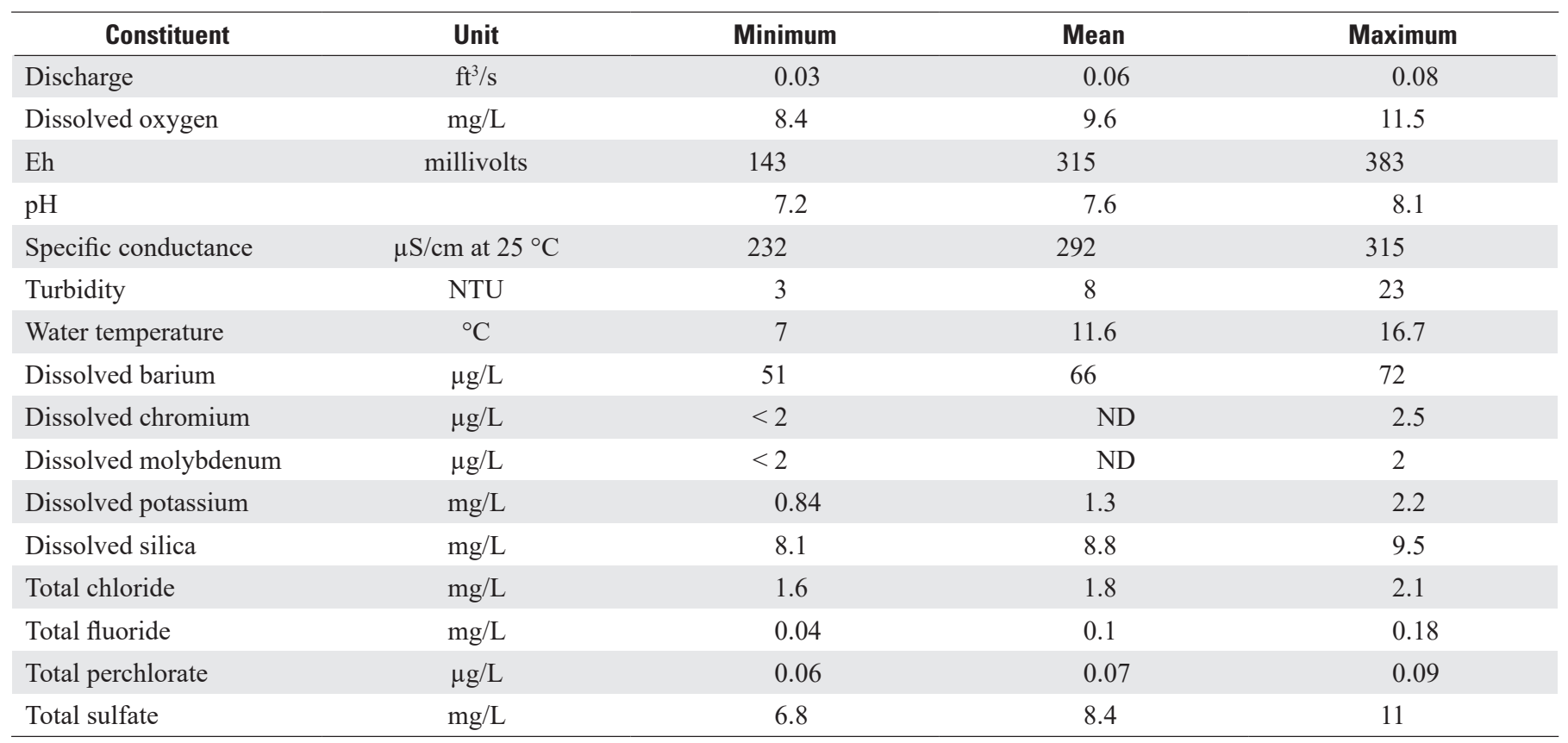

0.41 and $0.80 \mu \mathrm{g} / \mathrm{L}$, respectively; acetone and chloromethane were detected at $7.2 \mathrm{mg} / \mathrm{L}$ (acetone $\mathrm{RDL}=10 \mu \mathrm{g} / \mathrm{L}$ ) and $0.35 \mu \mathrm{g} / \mathrm{L}$, respectively, in November; and dichloromethane was detected at $0.87 \mu \mathrm{g} / \mathrm{L}$ in December. The RDLs for bromomethane, chloromethane, and dichloromethane are $1.0 \mu \mathrm{g} / \mathrm{L}$ (appendix 3). Note that bromomethane was detected in blank samples for surface water at concentrations ranging from 0.51 to $0.66 \mu \mathrm{g} / \mathrm{L}$. Acetone was detected in blank samples for groundwater but not surface water. Chloromethane was detected at $0.40 \mu \mathrm{g} / \mathrm{L}$ in a blank sample submitted in November 2016 for surface water. Dichloromethane was detected at $0.47 \mu \mathrm{g} / \mathrm{L}$ in a blank sample submitted in Dec. 2016 for surface water. Perchlorate, a semi-volatile organic compound, was detected at less than the RDL $(\mathrm{RDL}=0.2 \mu \mathrm{g} / \mathrm{L})$ in each sample collected at SW-U with a mean total concentration of $0.07 \mu \mathrm{g} / \mathrm{L}$ (table 7) for the four samples collected.

\section{Soil}

Soil samples from the nine soil sampling sites were collected from September to December 2016. Soil sites SO-5 and SO-6 were not sampled in December 2016 because asphalt had been spread over the sites in early December 2016. Four sites (SO-1, SO-4, SO-7, and SO-8) had typical A grading into E horizons down to a 6-inch depth. A horizons are below the organic layer (O horizon) of roots and organic debris and contain only some organic matter. The $\mathrm{E}$ horizon contains only limited organic matter. Both A and E horizons are mineral horizons where all parent rock material has been obliterated (U.S. Department of Agriculture, 2018b). The other soil sites sampled appear to have been affected by activities at LEAD. Sites SO-2 and SO-3 have very compact soils. SO-2 appeared to have fill material near the surface, but it did not have significant shale fragments. SO-3 has rock/cobble in the 0 - to 6-inch depth below the surface, and this also appeared to be fill material. Sites SO-5, SO-6, and SO-9 have shale fill at the surface down to a depth of 6 inches. The shale is interspersed with finer particles of sand and silt.

Analytical results for soils show that only one constituent, As, exceeded acceptable limits established by the Commonwealth of Pennsylvania (Pennsylvania Department of Environmental Protection, 2018) or the U.S. Environmental Protection Agency (2015). The Commonwealth of Pennsylvania has established medium-specific concentrations (MSCs) for soil that vary depending on the method used in calculating the MSC. The Commonwealth of Pennsylvania calculates MSCs based on health concerns if the soil is directly contacted. The EPA derives acceptable concentrations of constituents in soil (referred to as soil screening levels [SSLs]) based on standardized equations combining exposure information assumptions with EPA toxicity data. The EPA calculates SSLs for residential and industrial sites (U.S. Environmental Protection Agency, 2015). The soils at the ARMD site are considered "industrial" or "nonresidential" for comparative purposes. None of the As concentrations in soil exceeded the Pennsylvania MSC; however, all the As concentrations in soil exceeded the EPA SSL for As. Arsenic concentrations in soil ranged from 5.2 to $20.8 \mathrm{mg} / \mathrm{kg}$ (fig. 15 and appendix 4). The EPA SSL for As is $3 \mathrm{mg} / \mathrm{kg}$. According to the Commonwealth 
of Pennsylvania, the surface soil ( $0-2$ feet) nonresidential MSC for As is $61 \mathrm{mg} / \mathrm{kg}$. The Pennsylvania MSC for As is based on direct human contact, whereas the EPA SSL is based on assumptions made for exposure and toxicity. EPA (2018) notes that some SSL values may be less than background concentrations because the SSLs are purely risk based and that "Arsenic, aluminum, iron and manganese are common elements in soils that have background levels that may exceed risk-based SLs. This does not mean that these metals cannot be site-related, or that these metals should automatically be attributed to background."

The inorganic constituents with the highest concentrations in soil samples were $\mathrm{Fe}$ and $\mathrm{Al}$ (fig. 16). Mean Fe concentrations ranged from $28,700 \mathrm{mg} / \mathrm{kg}$ for SO-7 to $52,400 \mathrm{mg} / \mathrm{kg}$ for SO-9. Mean Al concentrations ranged from $10,300 \mathrm{mg} / \mathrm{kg}$ for SO-7 to $19,800 \mathrm{mg} / \mathrm{kg}$ for SO-9.

Another element found at relatively high concentrations in soils was $\mathrm{SiO}_{2}$. The mean $\mathrm{SiO}_{2}$ concentrations ranged from $841 \mathrm{mg} / \mathrm{kg}$ for SO-2 to $1,550 \mathrm{mg} / \mathrm{kg}$ for SO-9 (fig. 17). Site SO-9 had been filled with shale in the past. $\mathrm{SiO}_{2}$ is the primary element in shale, followed by aluminum (Schultz and others, 1980). Native soils also are highly concentrated with these elements as shown in figures 16 and 17; however, it is likely that the shale fill at SO-9 contributed to the high concentrations of $\mathrm{SiO}_{2}$ and $\mathrm{Al}$ at this site. Mean concentrations of $\mathrm{SiO}_{2}$ and $\mathrm{Al}$ were highest at SO-9. The lowest $\mathrm{P}$ concentrations were detected at the shale-filled sites (SO-5, SO-6, and SO-9); the lowest mean concentration of $245 \mathrm{mg} / \mathrm{kg}$ was detected at SO-5 (fig. 17).

Some trace elements that were detected in soil but at low concentrations were $\mathrm{As}, \mathrm{Pb}, \mathrm{Hg}$, and $\mathrm{Se}$. The lowest mean concentrations for $\mathrm{As}, \mathrm{Pb}$, and $\mathrm{Hg}$ were detected in samples from site SO-6, at concentrations of 6.2, 16.4, and $0.029 \mathrm{mg} / \mathrm{kg}$, respectively. The highest mean concentrations for $\mathrm{As}$ and $\mathrm{Pb}$ were detected in samples from site SO-2, at concentrations of 12.6 and $31.2 \mathrm{mg} / \mathrm{kg}$, respectively (fig. 15). The mean Se concentration for all soil samples collected was $1.5 \mathrm{mg} / \mathrm{kg}$, with nine nondetects at RDLs ranging from 2.4 to $3.3 \mathrm{mg} / \mathrm{kg}$.

Inorganic constituents with very limited detec-

tion in any soil samples were $\mathrm{Cd}, \mathrm{Ag}$, and $\mathrm{Sn}$. All values for $\mathrm{Cd}$ and $\mathrm{Sn}$ were either estimated values less than the RDLs or nondetects. The RDLs for Cd and Sn were about $0.5-0.6$ and $2.5-3.0 \mathrm{mg} / \mathrm{kg}$, respectively. There were no $\mathrm{Ag}$ detections in any soil sample; the RDL for $\mathrm{Ag}$ is about $1.0 \mathrm{mg} / \mathrm{kg}$ (appendix 4).

Of the 53 VOCs analyzed in soil samples collected during Sep.-Dec. 2016, 4 were detected in soil samples (appendix 4). Concentrations of many VOCs in matrix-spike samples were either greater than or less than the acceptable ranges (appendix 4). Similar to inorganic constituents, the Commonwealth of Pennsylvania established MSCs, and the EPA established SSLs for VOCs in soils. None of the VOCs detected in the soils from the ARMD site were within three orders of magnitude of the MSCs or SSLs established. The VOCs detected at the ARMD site were dichloromethane, methyl tert-butyl ether (MTBE), tetrachloroethene, and acetone (appendix 4).
Dichloromethane was detected in each of the 34 soil samples collected, at concentrations ranging from 1.9 to $50.1 \mu \mathrm{g} / \mathrm{kg}$. All the dichloromethane results were greater than the RDLs. The highest dichloromethane concentration was detected in a sample from SO-7. Note that dichloromethane was detected at concentrations of 4.5 and $2.5 \mu \mathrm{g} / \mathrm{kg}$ in blanks submitted in Sept. and Nov. 2016, respectively. MTBE was detected in 50 percent of the samples collected, but all results were estimated values at less than the RDL (RDLs ranged from 1.7 to $2.6 \mu \mathrm{g} / \mathrm{kg}$ ). Note that MS/MSD recoveries for MTBE were less than the acceptable range for samples analyzed in Sept. and Dec. 2016. The maximum estimated MTBE concentration was $1.3 \mu \mathrm{g} / \mathrm{kg}$ for the samples collected at SO-2 and SO-4 in September 2016. Tetrachloroethene was detected at less than the RDL (RDLs ranged from 1.7-2.6 $\mu \mathrm{g} / \mathrm{kg}$ ) in 20 percent of soil samples collected. Tetrachloroethene was detected only in samples collected in Dec. 2016, and the maximum estimated concentration detected was $1.5 \mu \mathrm{g} / \mathrm{kg}$ from SO-7. Acetone was detected only in one sample. The only detection of acetone was $16.5 \mu \mathrm{g} / \mathrm{kg}$ (RDLs ranged from 8.4 to $12.8 \mu \mathrm{g} / \mathrm{kg}$ ) for SO-9 in December 2016 (appendix 4).

Perchlorate was detected at concentrations less than the RDL in 38 percent of the soil samples collected. The RDL range for perchlorate was $0.32-3.1 \mu \mathrm{g} / \mathrm{kg}$. Perchlorate was detected at three sites (SO-1, SO-2, and SO-9) in 3 of the 4 samples collected at those sites. The maximum estimated concentration of perchlorate detected was $1.4 \mu \mathrm{g} / \mathrm{kg}$ at SO-8. Perchlorate was not detected at SO-3, SO-4, and SO-5 (appen$\operatorname{dix} 4)$.

\section{Summary and Conclusions}

Letterkenny Army Depot (LEAD), located near Chambersburg, Pennsylvania, is a Federal government facility that provides supply and maintenance support to the U.S. Armed Forces. LEAD permitted and built a new destruction facility, which was completed in 2016. The Ammonium Perchlorate Rocket Motor Destruction (ARMD) Facility uses confined burning with emissions control to treat solid propellant rocket motors. The ARMD Facility includes static firing of full motors and containment and capture of the exhaust for treatment in a pollution abatement system. The system was designed so that there would be no waste streams to the external environment. The Code of Federal Regulations requires any hazardous waste disposal facility to have in place an environmental monitoring program. Redhorse Corporation, in coordination with the Pennsylvania Department of Environmental Protection (PADEP) and LEAD, drafted an environmental monitoring plan to implement at the ARMD site. A requirement of the environmental monitoring plan was to establish baseline conditions prior to the beginning of facility operation in January 2017. The U.S. Geological Survey, in cooperation with Letterkenny Army Depot, conducted a study to measure the characteristics and constituents in groundwater, 

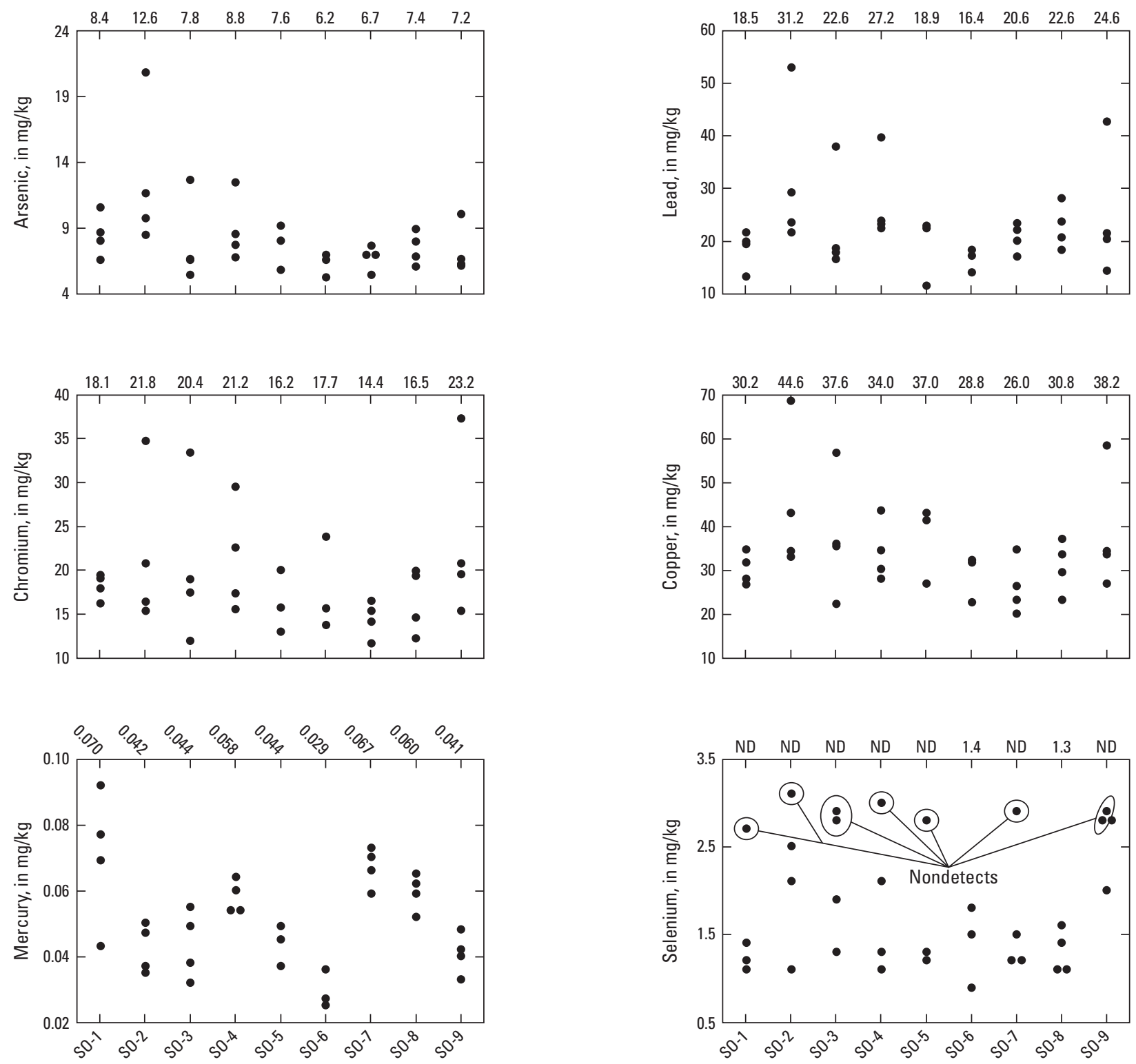

Figure 15. Measured and mean concentrations of arsenic, lead, chromium, copper, mercury, and selenium in soil samples collected from the nine soil sites at the Ammonium Perchlorate Rocket Motor Destruction Facility at the Letterkenny Army Depot, Pennsylvania, September-December 2016.

(Mean values are given at top of plot; ND, not determined; $\mathrm{mg} / \mathrm{kg}$, milligrams per kilogram)

surface water, and soil during a baseline period from Sep. to Dec. 2016. Baseline samples were collected monthly from September to December 2016 prior to facility operation. The monitoring program approach was to establish baseline concentrations of indicator compounds that could result from unplanned releases to soil, surface water, groundwater, stormwater runoff, or runoff sediment from the ARMD Facility; however, since samples were collected only in fall and early winter, any seasonal variability in constituents was not captured.

The sampling sites of the original monitoring plan included 4 groundwater wells, 4 surface-water sites, 9 soil sites, and 2 sediment sampling sites, which were in and immediately downgradient from culverts that drain the facility. The four monitoring wells, with depths ranging from 41 to 81 feet, were upgradient (one well) and downgradient (three wells) from the facility. The four stream sites were upgradient (one site) and downgradient (three sites) from the facility. The nine soil sites were within a few hundred yards of the facility buildings. The culverts designated for sediment sampling are at the front of the facility grounds, draining parking areas, access roads, and adjacent grounds. During the baseline period, there was no water in the downgradient stream locations, so surface-water samples were collected only at the upgradient site during the baseline period, and this surface water was only representative of the forested environment 

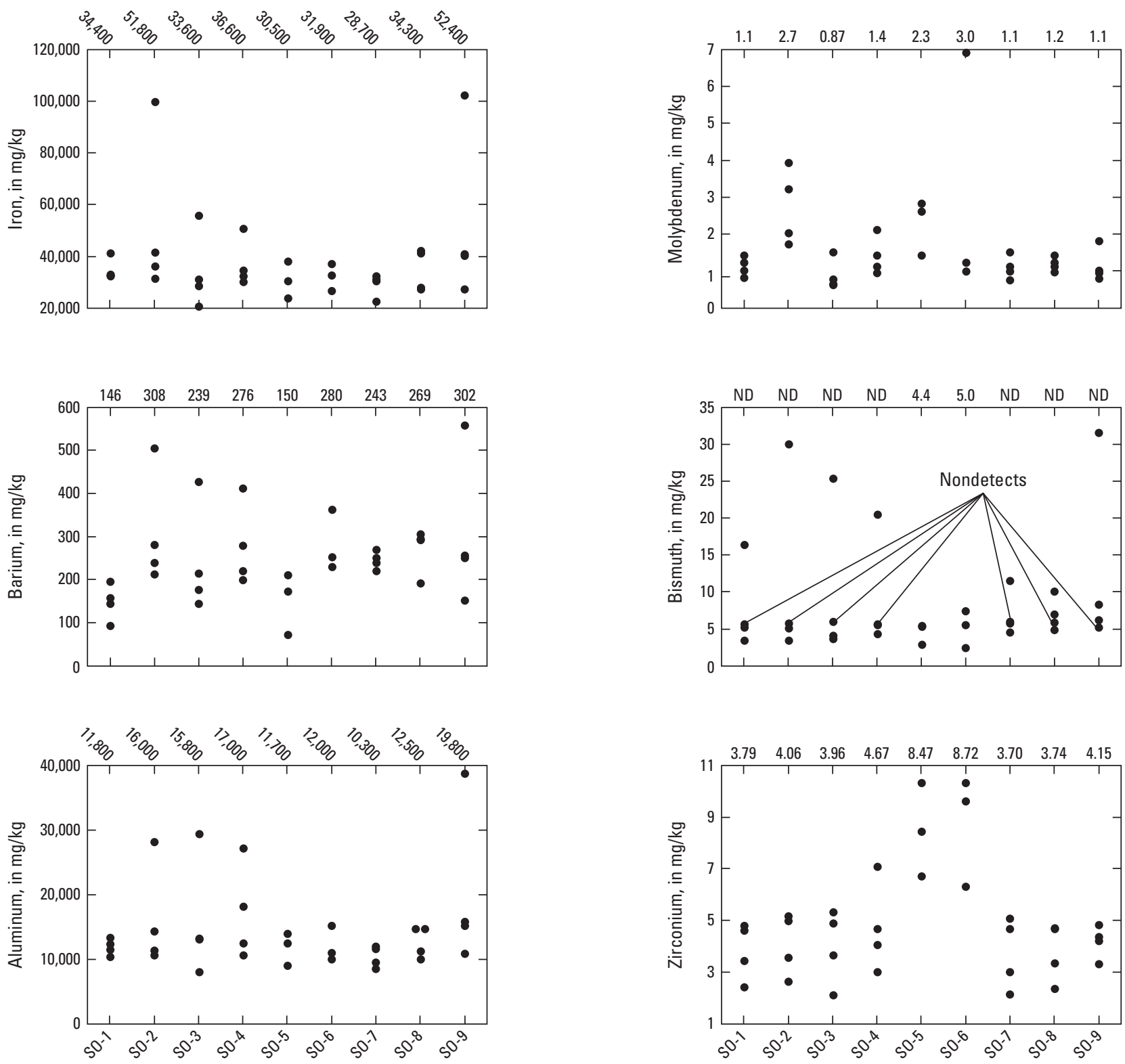

Figure 16. Measured and mean concentrations of iron, molybdenum, barium, bismuth, aluminum, and zirconium concentrations in soil samples collected from the nine soil sites at the Ammonium Perchlorate Rocket Motor Destruction Facility at the Letterkenny Army Depot, Pennsylvania, September-December 2016.

(Mean values are given at top of plot; ND, not determined; $\mathrm{mg} / \mathrm{kg}$, milligrams per kilogram)

upgradient from the ARMD Facility. There also was no sediment in the culverts draining the facility grounds, so no sediment was collected during the baseline period. Water and soil samples were analyzed for trace metals, major ions, volatile organic compounds (VOCs), zirconium, and perchlorate.

Quality assurance and quality control samples collected during the baseline period indicated some sampling and analytical bias based on the results from blank water samples. Analytical results from blanks submitted by sampling personnel to the ALS laboratory and internal blanks analyzed by the ALS laboratory indicated some contamination. All detections in blank water samples were less than the Reporting Detection
Level (RDL) for each constituent. Total chloride (Cl) was detected at less than the RDL with values ranging from 0.18 to 0.49 milligrams per liter $(\mathrm{mg} / \mathrm{L})$ in numerous blanks submitted for groundwater and surface-water samples. VOCs detected in blank water samples include acetone, bromomethane, and chloromethane. Acetone, bromomethane, and chloromethane were detected in numerous blanks at concentrations ranging from 3.6 to $6.6,0.40$ to 0.69 , and 0.40 to 0.55 micrograms per liter $(\mu \mathrm{g} / \mathrm{L})$, respectively. Internal laboratory blanks submitted for soil samples also had $\mathrm{Cl}$ detections (1.6-5.3 milligrams per kilogram $[\mathrm{mg} / \mathrm{kg}]$ ) less than the RDL. Fluoride (F), sulfate (SO4), and phosphorus (P) were also detected in blank soil 

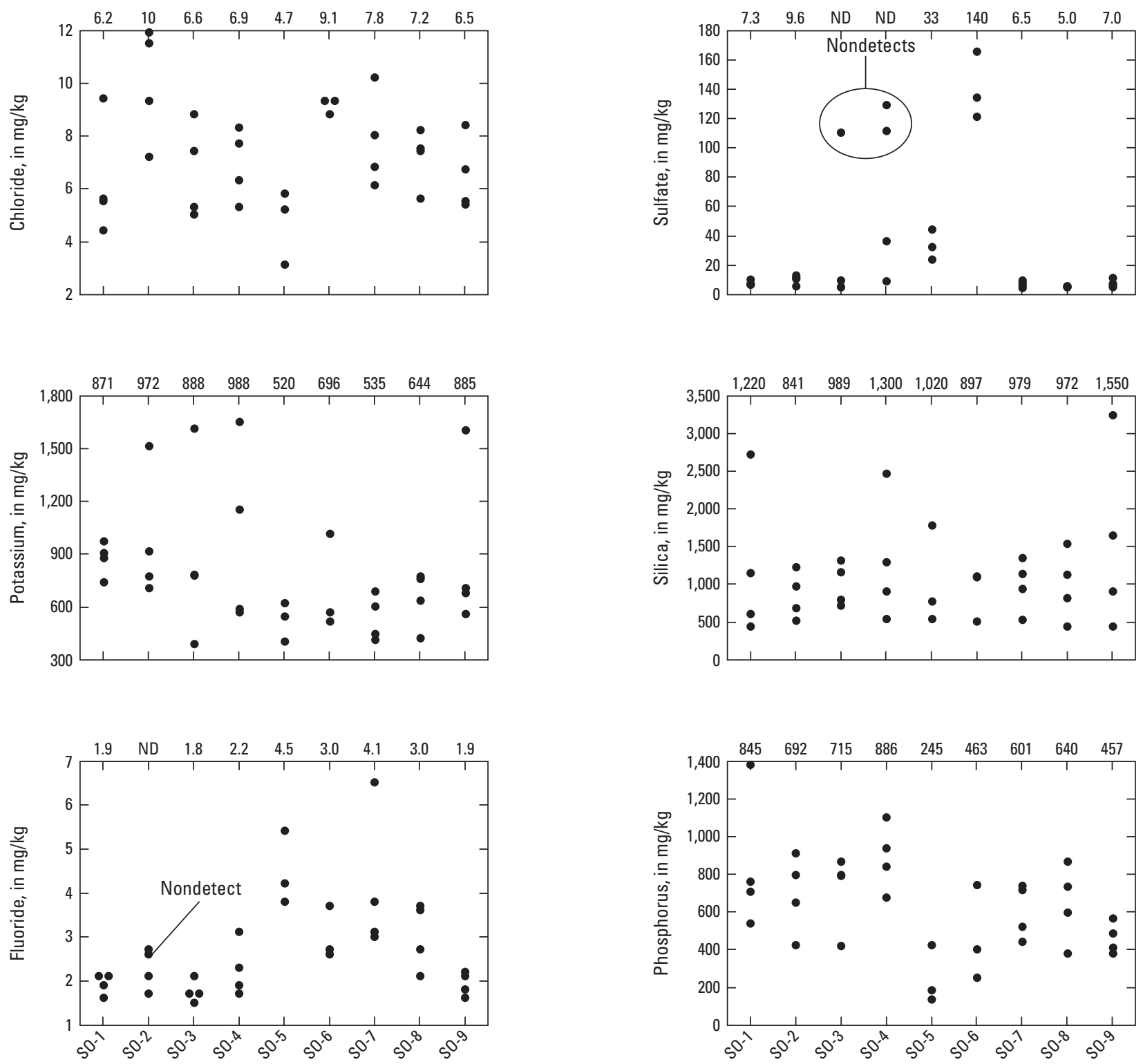

Figure 17. Measured and mean concentrations of chloride, sulfate, potassium, silica, fluoride, and phosphorus in soil samples collected from the nine soil sites at the Ammonium Perchlorate Rocket Motor Destruction Facility at the Letterkenny Army Depot, Pennsylvania, September-December 2016.

(Mean values are given above plot; ND, not determined; $\mathrm{mg} / \mathrm{kg}$, milligrams per kilogram)

samples at concentrations ranging from 0.3 to $0.6,13.6$ to 18.0 , and 0.92 to $4.1 \mathrm{mg} / \mathrm{kg}$, respectively. Dichloromethane was the only VOC detected in blank soil samples, and this was detected in two blanks at concentrations (2.5 and 4.5 micrograms per kilogram $[\mu \mathrm{g} / \mathrm{kg}]$ ) greater than the RDL. Replicate samples collected from water and soil matrices during the baseline period indicated that reproducibility for water samples was fairly high. Relative percent differences for replicated water samples typically were less than 5 percent. In contrast, reproducibility for soil samples was fairly low, with replicated samples showing a relative percent difference of more than 20 percent for most constituents that were detected.
Many VOCs were not detected in either the routine or replicate soil samples.

Groundwater results for the four wells sampled near the ARMD Facility during the baseline period did not show any major water-quality issues. All the wells were completed in the Martinsburg Formation, but mean specific conductance (SC) and $\mathrm{pH}$ in the groundwater ranged from 220 to 771 microsiemens per centimeter at 25 degrees Celsius $(\mu \mathrm{S} / \mathrm{cm})$ and 6.45 to 6.98 , respectively, indicating that shallow (within 50 feet of land surface) groundwater quality in the western part of the well field was being affected by proximity to the Chambersburg Formation (an argilaceous limestone). No constituents in groundwater samples exceeded any U.S. Environmental 
Protection Agency (EPA) Maximum Contaminant Level (MCL). Dissolved iron (Fe) was the only groundwater constituent that exceeded a Secondary Maximum Contaminant Level (SMCL) established by the EPA. The SMCL for Fe is 300 micrograms per liter $(\mu \mathrm{g} / \mathrm{L})$, and samples from 3 of 4 wells exceeded this value, with exceedance values ranging from 1,100 to $2,600 \mu \mathrm{g} / \mathrm{L}$. The only VOCs detected in groundwater samples were bromomethane, acetone, and chloromethane. All VOC detections in groundwater samples were less than the RDLs. Detections of bromomethane, acetone, and chloromethane ranged from 0.41 to $0.67,3.4$ to 5.4 , and 0.44 to $0.46 \mu \mathrm{g} / \mathrm{L}$, respectively. Bromomethane, acetone, and chloromethane were also detected in blank samples with values ranging from 0.40 to $0.65 \mu \mathrm{g} / \mathrm{L}, 5.2$ to $5.8 \mu \mathrm{g} / \mathrm{L}$, and 0.43 to $0.55 \mu \mathrm{g} / \mathrm{L}$, respectively. Perchlorate was not detected in any groundwater samples collected during the baseline period.

Surface-water data collected during the baseline period were strictly representative of a stream reach upgradient (SW-U) from the ARMD Facility. There was no streamflow evident at the time of sample collection at the three downgradient surface-water sites. Stream discharge ranged from 0.03 to 0.08 cubic feet per second during sample collection, indicating flows were primarily groundwater in origin and not storm-related subsurface flow or surface runoff. The mean $\mathrm{SC}$ and $\mathrm{pH}$ for baseline samples collected at SW-U were $315 \mu \mathrm{S} / \mathrm{cm}$ and 7.6, respectively. The relatively high SC for a forested basin and the slightly alkaline $\mathrm{pH}$ are reflective of the underlying limestone formation. No EPA established MCLs or SMCLs were exceeded for any constituents in samples collected from SW-U. Similar to groundwater results, some VOCs were detected in surface water at less than the RDLs. The VOCs detected in surface water were generally the same VOCs detected at less than the RDLs for groundwater. These were the same VOCs detected in blank water samples. Perchlorate was detected in each surface-water sample collected at SW-U, with a mean concentration of $0.07 \mu \mathrm{g} / \mathrm{L}$. All perchlorate results were less than the RDL of $0.2 \mu \mathrm{g} / \mathrm{L}$.

Soil samples collected near the ARMD Facility during the baseline period had only one constituent, arsenic (As), that exceeded EPA soil screening levels (SSLs). No soil mediumspecific concentrations (MSCs) established by the Commonwealth of Pennsylvania were exceeded. Soil As concentrations ranged from 5.2 to $20.8 \mathrm{mg} / \mathrm{kg}$. The EPA SSL for As is $3 \mathrm{mg} / \mathrm{kg}$; however, EPA acknowledges that "Arsenic, aluminum, iron and manganese are common elements in soils that have background levels that may exceed risk-based SSLs."

The inorganic constituents most commonly detected were $\mathrm{Fe}$ and aluminum (Al), with mean $\mathrm{Fe}$ and $\mathrm{Al}$ concentrations ranging from 28,700 to 52,400 and 10,300 to $19,800 \mathrm{mg} / \mathrm{kg}$, respectively. Four VOCs were detected in soil samples collected during the baseline period. None of the VOCs detected in the soils were within three orders of magnitude of any MSCs or SSLs. The VOCs detected in soil were dichloromethane (also known as methylene chloride), methyl tert-butyl ether (MTBE), tetrachloroethene, and acetone (only detected once). Dichloromethane was the only VOC detected at greater than the RDL, with concentrations ranging from 1.9 to $50.1 \mu \mathrm{g} / \mathrm{kg}$, all greater than the RDL. Dichloromethane was also detected at concentrations ranging from 2.5 to $4.5 \mu \mathrm{g} / \mathrm{kg}$ in blank samples analyzed for soil samples.

MTBE was detected in 50 percent of soil samples collected, but all results were less than the RDLs of $2-3 \mu \mathrm{g} / \mathrm{kg}$. However, matrix-spike results indicate that $\mathrm{MTBE}$ recoveries were less than the acceptable range for Sept. and Dec. 2016 samples. The maximum estimated MTBE value in a soil sample was $1.3 \mu \mathrm{g} / \mathrm{kg}$. Tetrachloroethene was detected at less than the RDL in 20 percent of soil samples collected, with a maximum estimated concentration of $1.5 \mu \mathrm{g} / \mathrm{kg}$.

\section{References Cited}

ArcGIS, 2009, USA Topo Maps, accessed on various dates at http://www.arcgis.com/home/item.html?id=99cd5fbd 98934 $028802 \mathrm{~b} 4 \mathrm{f} 797 \mathrm{c} 4 \mathrm{~b} 1732$.

Becher, A.E., and Taylor, L.E., 1982, Groundwater resources in the Cumberland and Contiguous Valleys of Franklin County, Pennsylvania: Harrisburg, Pa., Pennsylvania Geologic Survey, Water Resource Report 53, Fourth Series, $67 \mathrm{p}$.

Berg, T.M., Edmunds, W.E., Geyer, A.R., and others, comps., 1980, Geologic map of Pennsylvania (2d ed.): Pennsylvania Geological Survey, 4th ser., Map 1, scale 1:250,000, 3 sheets, https://mrdata.usgs.gov/geology/state/map.html.

Code of Federal Regulations (CFR), 2018, Title 40 Protection of Environment, Part 264 Standards for Owners and Operators of Hazardous Waste Treatment, Storage, and Disposal Facilities, Subpart F Releases from Solid Waste Management Units, accessed August 28, 2018 at http://www.ecfr. gov/cgi-bin/text-idx?SID=f253f25455f4fb6dd5cc40faf9f0c baf $\& m c=$ true $\&$ node $=$ sp40.26.264. $\&$ rgn $=\operatorname{div} 6$.

Francy, D.S., Jones, A.L., Myers, D.N., Rowe, G.L., Eberle, M., and Sarver, K.M., 1998, Quality-assurance/qualitycontrol manual for collection and analysis of water-quality data in the Ohio District: U.S. Geological Survey WaterResources Investigations Report 98-4057, 71 p.

Freeze, R.A., and Cherry, J.A., 1979, Groundwater: Englewood Cliffs, N.J., Prentice-Hall, Inc., 604 p.

Galeone, D.G., 2019, Quality control and soil quality data in support of baseline environmental monitoring at the Ammonium Perchlorate Rocket Motor Destruction (ARMD) Facility at the Letterkenny Army Depot, Chambersburg, Pennsylvania, 2016: U.S. Geological Survey data release, https://doi.org/10.5066/P973YRPL. 
Greenberg, A.E., Clesceri, L.S., and Eaton, A.D., 1992a, Acidity-titration method, in Standard methods for the examination of water and wastewater (18th ed.): American Public Health Association, p. 2-23 to 2-25.

Greenberg, A.E., Clesceri, L.S., and Eaton, A.D., 1992b, Solids, in Standard methods for the examination of water and wastewater (18th ed.): American Public Health Association, p. $2-53$ to $2-58$.

National Oceanic and Atmospheric Administration, 2018a, NOWData monthly summaries, accessed May 10, 2019, at http://w2.weather.gov/climate/xmacis.php?wfo=ctp.

National Oceanic and Atmospheric Administration, 2018b, National Weather Service Advanced Hydrologic Prediction Service, radar derived precipitation estimates, accessed May 10, 2019, at https://water.weather.gov/precip/.

O’Dell, J.W., ed., 1993, Method 365.1: Determination of phosphorus by semi-automated colorimetry, Revision 2.0: Cincinnati, Ohio, Environmental Monitoring Systems Laboratory, Office of Research and Development, U.S. Environmental Protection Agency, accessed December 13, 2017, at https://www.epa.gov/sites/production/files/201508/documents/method_365-1_1993.pdf.

Pennsylvania Department of Environmental Protection, 2018, Statewide Health Standards, accessed May 15, 2019, at https://www.dep.pa.gov/Business/Land/LandRecycling/ Standards-Guidance-Procedures/Pages/Statewide-HealthStandards.aspx.

Pennsylvania State Climatologist, 2018, State wide data, accessed July 10, 2018, at http://climate.psu.edu/data/state/ regional.php\#division4.

Pfaff, J.D., 1993, Method 300.0: Determination of inorganic ions by ion chromatography, revision 2.1: Cincinnati, Ohio, Environmental Monitoring Systems Laboratory, Office of Research and Development, U.S. Environmental Protection Agency, accessed December 13, 2017, at https:// www.epa.gov/sites/production/files/2015-08/documents/ method_300-0_rev_2-1_1993.pdf.

Redhorse Corporation, 2016, Environmental sampling plansoil, groundwater, and surface water quality monitoring for the Ammonium Perchlorate Rocket Motor Destruction (ARMD) Facility: San Diego, Calif., Redhorse Corporation, prepared for Letterkenny Army Depot, revised May 2016, $58 \mathrm{p}$.

Schultz, L.G., Tourtelot, H.A., Gill, J.R., and Boerngen, J.G., 1980, Composition and properties of the Pierre Shale and equivalent rocks, Northern Great Plains Region: U.S. Geological Survey Professional Paper 1064, 114 p. [Also available at https://pubs.er.usgs.gov/publications/pp1064B.]
U. S. Department of Agriculture, 2018a, Natural Resource Conservation Service, Web Soil Survey: U.S. Department of Agriculture, accessed July 11, 2018, at https:// websoilsurvey.nrcs.usda.gov/app/WebSoilSurvey.aspx.

U. S. Department of Agriculture, 2018b, Soil Survey Manual, U.S. Department of Agriculture Handbook No. 18, 603 p.

U. S. Environmental Protection Agency, 1994, EPA Method 7470A (SW-846) - Mercury in liquid wastes (Manual coldvapor technique), revision 1: U.S. Environmental Protection Agency, accessed December 12, 2017, at https://www.epa. gov/homeland-security-research/epa-method-7470a-sw846-mercury-liquid-wastes-manual-cold-vapor-technique.

U. S. Environmental Protection Agency, 1996a, SW-846 Test Method 8260B - Volatile organic compounds by Gas Chromatography/Mass Spectrometry (GC/MS): U.S. Environmental Protection Agency, accessed December 12, 2017, at https://www.epa.gov/hw-sw846/sw846-test-method-8260b-volatile-organic-compounds-gaschromatographymass-spectrometry.

U. S. Environmental Protection Agency, 1996b, Method 6010B-Inductively Coupled Plasma-Atomic Emission Spectrometry: U.S. Environmental Protection Agency, accessed December 13, 2017, at http://www.caslab.com/ EPA-Methods/PDF/EPA-Method-6010B.pdf.

U. S. Environmental Protection Agency, 1998a, Method 6020A (SW-846) - Inductively Coupled Plasma-Mass Spectrometry, revision 1: U.S. Environmental Protection Agency, accessed December 12, 2017, at https://www.epa. gov/homeland-security-research/epa-method-6020a-sw846-inductively-coupled-plasma-mass-spectrometry.

U. S. Environmental Protection Agency, 1998b, Method 7471B (SW-846) - Mercury in solid or semisolid waste (Manual cold-vapor technique), revision 2: U.S. Environmental Protection Agency, accessed December 13, 2017 , at https://www.epa.gov/homeland-security-research/epamethod-7471b-sw-846-mercury-solid-or-semisolid-wastesmanual-cold.

U. S. Environmental Protection Agency, 2007a, Method 6010C (SW-846) - Inductively Coupled Plasma-Atomic Emission Spectrometry, revision 3: U.S. Environmental Protection Agency, accessed December 12, 2017, at https:// www.epa.gov/homeland-security-research/epa-method6010c-sw-846-inductively-coupled-plasma-atomicemission. 
U. S. Environmental Protection Agency, 2007b, Validated Test Method 6850-Perchlorate in water, soils and solid wastes using High Performance Liquid Chromatography/ Electrospray Ionization/Mass Spectrometry (HPLC/ESI/ MS or HPLC/ESI/MS/MS): U.S. Environmental Protection Agency, accessed December 12, 2017, at https://www.epa. gov/hw-sw846/validated-test-method-6850-perchloratewater-soils-and-solid-wastes-using-high-performance.

U. S. Environmental Protection Agency, 2009, National Primary Drinking Water Regulations: U.S. Environmental Protection Agency, EPA-816-F-09-004, 6 p.

U. S. Environmental Protection Agency, 2015, Regional screening level (RSL) summary table $(\mathrm{TR}=1 \mathrm{E}-06, \mathrm{HQ}=1)$ November 2015: U.S. Environmental Protection Agency, accessed July 13, 2018, at https://www.epa.gov/risk/ regional-screening-levels-rsls-generic-tables.

U. S. Environmental Protection Agency (EPA), 2018, Regional Screening Level (RSLs) user's guide-November 2018: U.S. Environmental Protection Agency, accessed May 2, 2019, at https://www.epa.gov/risk/regional-screeninglevels-rsls-users-guide.

U.S. Geological Survey, variously dated, National field manual for the collection of water-quality data: U.S. Geological Survey Techniques of Water-Resources Investigations, book 9, chap. A1-A9, accessed Aug. 1, 2016 at http://pubs. water.usgs.gov/twri9A/. 
Appendix 1. Description of wells and constituent concentrations in groundwater samples from four wells at the Ammonium Perchlorate Rocket Motor Destruction Facility at the Letterkenny Army Depot, Pennsylvania, September-December 2016.

Appendix_1.xlsx available for download at https://doi.org/10.3133/ofr20191094.

Appendix 2. Monthly ranges of volatile organic compounds in matrix-spike samples analyzed internally at ALS laboratory for soil samples submitted from the Ammonium Perchlorate Rocket Motor Destruction Facility at the Letterkenny Army Depot, Pennsylvania, September-December 2016.

Appendix_2.xlsx available for download at https://doi.org/10.3133/ofr20191094.

Appendix 3. Description of surface-water sites and constituents in surfacewater samples collected near the Ammonium Perchlorate Rocket Motor Destruction Facility at the Letterkenny Army Depot, Pennsylvania, September-December 2016.

Appendix_3.xlsx available for download at https://doi.org/10.3133/ofr20191094.

Appendix 4. Description of soil sites and constituent concentrations in soil samples collected at the Ammonium Perchlorate Rocket Motor Destruction Facility at the Letterkenny Army Depot, Pennsylvania, September-December 2016.

Appendix_4.xlsx available for download at https://doi.org/10.3133/ofr20191094. 
For additional information, contact:

Director, Pennsylvania Water Science Center

U.S. Geological Survey

215 Limekiln Road

New Cumberland, Pa. 17070

or visit our website at:

http://pa.water.usgs.gov/

Publishing support provided by the West Trenton Publishing Service Center 


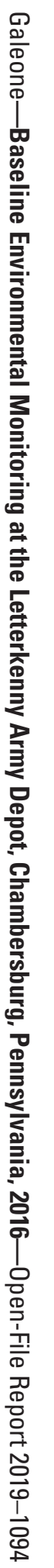

